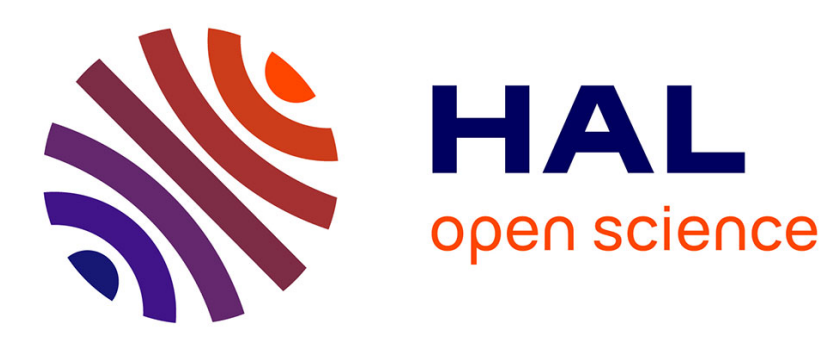

\title{
Multiple sources for tephra from AD 1259 volcanic signal in Antarctic ice cores
}

Biancamaria Narcisi, Jean Robert Petit, Barbara Delmonte, Valentina Batanova, Joel Savarino

\section{- To cite this version:}

Biancamaria Narcisi, Jean Robert Petit, Barbara Delmonte, Valentina Batanova, Joel Savarino. Multiple sources for tephra from AD 1259 volcanic signal in Antarctic ice cores. Quaternary Science Reviews, 2019, 210, pp.164-174. 10.1016/j.quascirev.2019.03.005 . hal-02350371

\section{HAL Id: hal-02350371 \\ https://hal.science/hal-02350371}

Submitted on 25 Nov 2020

HAL is a multi-disciplinary open access archive for the deposit and dissemination of scientific research documents, whether they are published or not. The documents may come from teaching and research institutions in France or abroad, or from public or private research centers.
L'archive ouverte pluridisciplinaire HAL, est destinée au dépôt et à la diffusion de documents scientifiques de niveau recherche, publiés ou non, émanant des établissements d'enseignement et de recherche français ou étrangers, des laboratoires publics ou privés. 


\title{
Manuscript Details
}

\section{Manuscript number}

Title
JQSR_2019_21

MULTIPLE SOURCES FOR TEPHRA FROM AD 1259 VOLCANIC SIGNAL IN ANTARCTIC ICE CORES

\begin{abstract}
Strong volcanic signals simultaneously recorded in polar ice sheets are commonly assigned to major low-latitude eruptions that dispersed large quantities of aerosols in the global atmosphere with the potential of inducing climate perturbations. Parent eruptions responsible for specific events are typically deduced from matching to a known volcanic eruption having coincidental date. However, more robust source linkage can be achieved only through geochemical characterisation of the airborne volcanic glass products (tephra) sometimes preserved in the polar strata. We analysed fine-grained tephra particles extracted from layers of the AD 1259 major bipolar volcanic signal in four East Antarctic ice cores drilled in different widely-spaced locations of the Plateau. The very large database of glassshard geochemistry combined with grain size analyses consistently indicate that the material was sourced from multiple distinct eruptions. These are the AD 1257 mega-eruption of Samalas volcano in Indonesia, recently proposed to be the single event responsible for the polar signal, as well as a newly-identified Antarctic eruption occurred in AD 1259. Finally, a further eruption that took place somewhere outside Antarctica has contributed to tephra deposition. Our high-resolution, multiple-site approach was critical to reveal spatial heterogeneity of tephra at the continental scale. Evidence from ice-core tephra indicates recurrent explosive activity at the Antarctic volcanoes and could have implications for improved reconstruction of post-volcanic effects on climate from proxy polar records.
\end{abstract}

\section{Submission Files Included in this PDF}

File Name [File Type]

AD1259_text_Jan_2019.docx [Manuscript File]

Fig1_sample position_dic18.pdf [Figure]

figura 2_V3.JPG [Figure]

Fig3_micro foto dic 2018.pdf [Figure]

Fig4_TAS_AD1259_thin+ comp.pdf [Figure]

Fig5_TASthin_trend TD.pdf [Figure]

Supplementary_AD1259_rev2019.docx [MethodsX]

To view all the submission files, including those not included in the PDF, click on the manuscript title on your EVISE Homepage, then click 'Download zip file'.

\section{Research Data Related to this Submission}

There are no linked research data sets for this submission. The following reason is given:

Microprobe single-grain data are given as Supplementary Material along with details of analytical conditions 


\section{MULTIPLE SOURCES FOR TEPHRA FROM AD 1259 VOLCANIC SIGNAL IN ANTARCTIC ICE CORES}

Biancamaria Narcisi ${ }^{1}$, Jean Robert Petit ${ }^{2}$, Barbara Delmonte ${ }^{3}$, Valentina Batanova ${ }^{4}$, Joël Savarino ${ }^{2}$

(1) ENEA, C.R. Casaccia, 00123 Roma, Italy, biancamaria.narcisi@enea.it

(2) Univ. Grenoble Alpes, CNRS, IRD, Grenoble INP, IGE, 38000 Grenoble, France

10 (3) Department of Earth and Environmental Sciences (DISAT), Univ. Milano-Bicocca, Piazza della Scienza, 20126 11 Milano, Italy

(4) Univ. Grenoble Alpes, Univ. Savoie Mont Blanc, CNRS, IRD, IFSTTAR, ISTerre, 38000 Grenoble, France

\section{Abstract}

Strong volcanic signals simultaneously recorded in polar ice sheets are commonly assigned to major low-latitude eruptions that dispersed large quantities of aerosols in the global atmosphere with the potential of inducing climate perturbations. Parent eruptions responsible for specific events are typically deduced from matching to a known volcanic eruption having coincidental date. However, more robust source linkage can be achieved only through geochemical characterisation of the airborne volcanic glass products (tephra) sometimes preserved in the polar stratn We ysed fine-grained tephra particles extracted from layers of the AD 1259 major bipc Iolcan... signal in four East Antarctic ice cores drilled in different widely-spaced locations of the Plateau. The very large database of glass-shard geochemistry combined with grain size analyses consistently indicate that the material was sourced from multiple distinct eruptions. $T^{-}=$are $\square$ AD 1257 mega-eruption of Samalas volcano in Indonesia, recently proposed $t \sqrt{ }$ : the $\ldots$ sle $\rightarrow$ it recnnnsible for the polar signal, as well as a newly-identified Antarctic eruptionfoccur reu in Al 59. Finally, a further eruption that took place somewhere outside/Antarctica has/contributed to tephra deposition. Our high-resolution, multiple-site approach was critical to reveat/spatial heterogeneity of tephra at the continental scale. Evidence from ice-core tephra indicates recurrent explosive activity at the Antarctic volcanoes and could have implications for improved reconstruction of post-volcanic effects on climate from proxy polar records. 


\section{Highlights}

- Significant tephra concentration in AD 1259 volcanic signal from four Antarctic ice cores

- Compositional heterogeneity of tephra suggests sourcing from multiple distinct eruptions

- Linkage of the Antarctic ice signal with the Samalas AD 1257 eruption confirmed

- A new Antarctic eruption that occurred in AD 1259 has been also identified

- Antarctic regional-scale effects of local volcanic activity conceivable

Key words: Cryptotephra; Antarctica; Ice Cores; Volcanic isochron; Glass shard microanalysis; Antarctic rifting volcanism; Samalas AD 1257 eruption 


\section{Introduction}

As it is documented in the vast literature produced during the last four decades, continuous volcanic profiles from polar ice sheets reconstructed by electric conductivity (ECM) and sulphate measurements are punctuated by prominent spikes recording explosive eruptions of the past (e.g., Hammer, 1980; Delmas et al., 1992; Langway et al., 1995; Severi et al., 2012; Sigl et al., 2014, 2015). These signals can be used both as reference horizons to provide independent age constraints for the ice core series, and to reconstruct the history of explosive volcanism and its relationship with climate. Volcanic events with bipolar occurrence are particularly interesting in this respect. These are typically interpreted as related to massive low-latitude events capable to produce sulphuric acidic deposition all over the world with the potential of forcing global climate (e.g., Langway et al., 1995; Sigl et al., 2015). Their record in both polar regions also enables direct north-south synchronisation of ice stratigraphies, which is of crucial importance to reconstruct the phasing of climatic events and understanding underlying mechanisms (Svensson et al., 2013).

Among the most outstanding volcanic deposition events of the las' nillennia (Sigl et al., 2014), peak fallout of volcanic aerosols over the poles dated/ 1259 represents a fundamental age marker for ice chronologies. Its signal is recorded in several Greenland and Antarctic ice cores, and was initially identified by Langway et al. (1988), who suggested that the parent volcano could be probably located in the Northern Hemisphere close to Equator. Since then, numerous papers have considered various aspects of this event (e.g. Delmas et al., 1992; Zielinski, 1995; Stothers, 2000). Particularly, its source has been a matter of debate as until recently no record of large volcanic eruption around that date was known. On the basis of analysis of tiny glass shards, Palais et al. (1992) suggested that the material from Greenland and South Pole (SP) ice levels is indeed from the same volcano, and identified El Chichón, Mexico, as the probable source, despite the chemical match was not perfect in detail. Oppenheimer (2003) presented the hypothesis of a super-eruption of global significance or a smaller eruption enriched in sulphur. Baroni et al. (2008) used sulphur isotope analysis to indicate a stratospheric nature for the volcanic signals at the Antarctic Dome C and SP sites. More recently, a major caldera explosive event was identified at Samalas volcano, on Lombok Island, Indonesia (Lavigne et al., 2013, Vidal et al., 2015, 2016; Alloway et al., 2017). Based upon chronostratigraphic and geochemical studies nearby the source, and the analysis of historical texts, this eruption of exceptional size was dated at AD 1257, placed at the end of the Medieval Warm Period (ca. 900-1250 A.D., Mann et al., 2009). It has been inferred to be the single counterpart of the AD 1259 bipolar spike. In particular, according to a recent reconstruction of Antarctic continental-scale volcanic aerosol deposition, the sulphate injection greatly exceeded that of the AD 1815 cataclysmic Tambora eruption (Sigl et al., 2014).

When strong explosive volcanic eruptions occur, large quantities of solid particles (tephra) and gases penetrate the tropopause and rise to altitudes well within the stratosphere, where they can be distributed all around the globe. Tephra fallout can affect vast regions, and small particles can be deposited thousands of kilometres from active sources forming invisible horizons (e.g., Lowe, 2011; Ponomareva et al., 2015, and references therein). The fingerprint of volcanic material preserved in distant sites can univocally identify source areas and could be employed to disentangle the origin of volcanic glacio-chemical signals in polar ice cores 
(e.g., Yalcin et al., 2006; Dunbar et al., 2017), that otherwise is conjectured from the record of documented eruptions. However, especially for tropical-equatorial eruptions the amount of tephra that could be dispersed towards the poles is typically very small and the material very fine-grained, making such tephra study very challenging.

A preliminary exploratory investigation of a shallow Antarctic ice core from the ConcordiaDome C site revealed evidence of an appreciable concentration of cryptotephra in connection with the AD 1259 sulphate peak (Petit et al., 2016). This intriguing observation prompted us to carry out a detailed tephra study in order to make inferences about source(s) that produced the tephra and to discuss the related atmospheric implications. In this work we describe the characteristics of the glassy volcanic material associated with the AD 1259 signal in different sectors of the East Antarctic Plateau (EAP). We took advantage of having access to various good-quality ice cores covering the last millennium to apply a multiple core approach that allows highlighting the spatial distribution of volcanic products. Note that while attempts to identify the parent eruption of major polar signals through a tephra study often rely on few shards (e.g., Zielinski et al., 1997; Barbante et al., 2013), here we obtained a large dataset based on a considerable amount of electron probe microanalyses that allows recognizing compositional heterogeneities within tephra, in association with ash grain size measurements. We also considered an inventory of candidate source volcanoes more extended than that employed in previous studies.

\section{Materials and Methods}

In this study we used 4 EAP ice cores located at elevations between 1950 and $3488 \mathrm{~m}$ (Figure 1 and Table S1). Two core sites, Dome C-Concordia (DC) and Vostok (VK), are located 600 $\mathrm{km}$ apart in the central, inner sector of the Plateau, and two, Talos Dome-TALDICE (TD) and GV7, are $200 \mathrm{~km}$ apart in peripheral position facing the Ross Sea. They show different modern climate and atmospheric characteristics (e.g., Masson-Delmotte et al., 2011) as well as distance from the Quaternary volcanoes of the Antarctic rift provinces. All the cores used have an undisturbed stratigraphy and are provided with a detailed volcanic aerosol profile, either as sulphate or ECM measurements. They all show the broad and pronounced signal unambiguously related to the AD 1259 event that occurs at variable depth depending on the accumulation rate of the site (between $29.6 \mathrm{~m}$ at VK and $181.9 \mathrm{~m}$ at GV7, Figure 1a).

Since at the visual core inspection no macroscopic evidence for the presence of tephra was detected, the core depth intervals corresponding to the volcanic spike were sub-sampled continuously, albeit with different resolution $(5$ to $15 \mathrm{~cm}$ ) depending on the local accumulation rate. Processing of subsamples for laboratory measurements was carried out under clean conditions. To reduce contamination of samples to a minimum, the outer portion of porous firn samples was removed with a clean ceramic knife while ice pieces were washed thrice in ultrapure water. The resulting decontaminated samples were then melted and an aliquot was used for quantitative measurements of dust concentration and size distribution using a Coulter Counter set up in a class 100 clean room (Delmonte et al., 2002). The only exception relates to the GV7 core, where presence of abundant drilling fluid prevented accurate Coulter Counter measurements. A separate aliquot of meltwater from levels showing unusually high concentration of particles with respect to the local background was filtered (nucleopore polycarbonate membranes) for tephra recovery. Filters were examined using light and scanning electron microscopes, and typical tephra grains were 
photographed (Figure 4). To investigate the source for the recovered material, we determined the major element composition of individual shards using the electron microprobe set up at the Institut des Sciences de la Terre (ISTerre) of Grenoble. The operating details are given in the Supplementary Material.

136 From the initial geochemical dataset (over 900 analyses) collected during different sessions, we cautiously discarded analytical data showing total oxide sums $\leq 60 \%$ and those nhviously related to pure minerals (quartz, plagioclase, metals, etc.). The rest, consisting $\sim 320$ measurements generally made on very small individual glass particles, was normalised to $100 \%$ total oxide values for subsequent interpretation. We expect a decrease of precision but after normalisation all the elements with oxide contents $>1 \%$ can be considered robust enough for interpretation (Iverson et al., 2017).

\section{Results}

EAP core samples selected at the culmination of the volcanic spike show microparticle concentrations well above background levels for each site (Fig. 2). Central Plateau samples show concentrations higher (a factor 6 to 10) than background levels for firn ( $8 \mathrm{ppb}$, Delmonte et al., 2013) and mass size distributions well-defined around modal values smaller than background ( $2 \mu \mathrm{m}$ on average during Holocene, Delmonte et al., 2005). For DC, the mode is around $1.7 \mu \mathrm{m}$, while for VK it is between $1.3 \mu \mathrm{m}$ and $1.9 \mu \mathrm{m}$ respectively for samp' VK-16 and VK-14, although some very large particles up to $\sim 20 \mu \mathrm{m}$ were included in $t$

151 latter.

152

TD sample 87-1 from the base of the volcanic sulphate peak shows very large particles with mass modal values as high as $\sim 6 \mu \mathrm{m}$, associated. Poncentration levels higher than $\sim 10$ times background levels for firn ( 12 ppb, Delmonte et al., 2013). From the lowermost to the uppermost part of the volcanic spike (see Figure 1a for stratigraphic position of the samples), a progressive decrease in microparticle concentration and size can be observed. A population of particles larger than $\sim 5 \mu \mathrm{m}$ is present in the two deepest samples (TD $87-1$ and 86-4), while the relative abundance of particles smaller than $2 \mu \mathrm{m}$ increases upward within the peak. We note that sample 86-4 shows a bimodal distribution with a first mode smaller than $2 \mu \mathrm{m}$ and a larger mode around 4-6 $\mu \mathrm{m}$.

At the microscopic inspection, glass particles generally display well-preserved textures with no traces of abrasion strongly suggesting that the material was not subject to reworking (Figure 3). Among the examined samples, TD 87-1 and 86-4 contain pumice particles with elongated vesicles up to ca. 40-50 $\mu \mathrm{m}$ long along with fine-size shards remnants of thin vesicle walls. Particles in the filters from the inner EAP cores are typically represented by tiny curved and platy-like shards. Material from: Jle VK-14 contains glass particles up to 15-20 $\mu \mathrm{m}$ in size. Microscopic observations couru with grain size analysis exclude that the volcanic material belongs to background dust, and instead provide compelling evidence of primary tephra deposition at levels within the AD 1259 acidity peak.

Results of grain-specific geochemical analysis are illustrated in Figs 4-5, where the data are plotted on the total alkali-silica (TAS) diagram. Silica co-variations with $\mathrm{K}_{2} \mathrm{O}, \mathrm{CaO}$, $\mathrm{FeO}$ and $\mathrm{Al}_{2} \mathrm{O}_{3}$, not shown here, are coherent in providing the same chemical pattern. Representative analyses of individual glass shards are presented in Table S3, along with biplot comparisons 
of selected major-oxide ratios in the present data and in published literature for further potential source volcanoes and equivalents (Supplementary Material).

The analysed glass shards, taken altogether, display variable silica contents, from intermediate to evolved compositions $\left(\mathrm{SiO}_{2}>52 \mathrm{wt} \%\right)$. No basic and ultrabasic geochemistries are represented. Within the glass heterogeneous composition spreading over three TAS fields, we identify two main separate clusters of data, one trachytic falling in the alkaline field, 63-65 wt \%, and the other showing sub-alkaline affinity and straddling the trachyte-dacite-rhyolite boundaries (for brevity referred to hereafter as 'dacitic'), $70 \mathrm{wt} \%$. A third subpopulation, subordinate in terms of frequency, shows a siliceous rhyolitic composition $\left(\mathrm{SiO}_{2}>74 \mathrm{wt} \%\right)$.

Volcanic glass composition also varies spatially (Figure 4a). Ice core shards from the Central EAP sites are predominantly sub-alkaline in composition. However, the three analysed samples display different characteristics. The very fine-grained DC sample and sample VK-14 also dominantly dacitic. Sample VK-16 displays two clusters of geochemical data. The main glass population is dacitic in composition and appears comparable with that in sample VK-14 and in DC, the subordinate population is a siliceous rhyolite. Sparse analyses from both VK samples fall within the trachytic glass group.

In all six ice sections from the two peripheral EAP sites trachytic tephra particles are dominating, but with occurrence of subordinate glass with different signature (Fig. 4a). At TD, we observe an interesting compositional variation with respect to the time-stratigraphic position of the samples (Figure 5). Volcanic ash on the TD 87-1 filter, situated at the very beginning of the sulphate fallout (Figure 1) and containing coarse particles, is mainly trachytic in composition. The adjacent TD 86-4 from the acme of the sulphate volcanic signal shows two main coexisting glass populations. This is consistent with the striking bimodal grain size distribution of this sample (Figure 2). According to scanning electron microscopic check during microprobe analysis, coarser particles correspond to trachyte, finer particles are mostly dacitic. Glass from the upper TD 86 samples -3 and -2 , stratigraphically located at the later part of the spike and populated by fine particles, is trachytic. GV7 ice shows coexisting trachytic and dacitic geochemistries (Figure 4a). The two analysed samples are equally heterogeneous (not shown). In all samples from the peripheral cores, only one shard from TD falls within the rhyolite cluster identified in VK-16 (Figure 4a).

\section{Interpretation and discussion}

\subsection{Identification of tephra sources}

Filters from all studied cores contain significant volcanic glass that appears heterogeneous both in grain size and geochemistry and present variable spatial characteristics.

Taken as a whole, the composition of glass shards allows two prevailing and a third subsidiary populations to be distinguished. Trachytic shards are more abundant in the samples from peripheral EAP sites, which are characterised by coarser grain size. Dacitic shards occur in all sites but are dominating in the Central EAP samples, typically characterised by smaller particle size. This pattern already suggests that tephra transport 
and deposition could be controlled by different atmospheric dynamics over the Plateau. Although tephra transport is very different from background dust input onto the EAP (Narcisi et al., 2005), mineral dust investigations highlighted that the periphery of the ice sheet in fact is influenced by regional atmospheric circulation dynamics of the Western Ross Sea, while sites from the inner part of the EAP are more sensitive to long-range high-altitude transport above Antarctica (e.g., Delmonte et al., 2013).

Focusing on the geochemical signature of volcanic glass as a major criterion for source identification, we first point out that compositional heterogeneity in a tephra horizon could be related to magmatic differentiation during a single parent explosive episode or to coeval deposition from separate events. Several examples of both types of tephra are known in Antarctic ice (e.g., Narcisi et al., 2016). Since alkaline (i.e. trachytic) composition and subalkaline (i.e. dacitic) composition typically pertain to different tectonic settings, here we interpret co-existing trachytic and dacitic tephras in the studied samples as related to contemporaneous eruptions from independent sources.

Alkaline trachytic compositions are characteristic of Antz $\because$ : volcanoes, belonging to one of the largest active alkali rift systems of the world (Wc .; 1989). Indeed the identified trachytic glass shards, particularly copious in the filters from peripher: res that are adjacent to Victoria Land volcanic provinces, is chemically very consistent with compositions of the tephra layers in the TALDICE core originated from local sources during the last climatic cycle (Narcisi et al., 2012, 2016, 2017) (Figure 4b). We therefore deduce that the trachytic glass in the studied samples was produced by a local Antarctic explosive eruption oceurred at $A D$ 1259. The coarse particle size observed at TD which is $\sim 200 \mathrm{~km}$ distant from the inferred source area, further su $\square$ ts this interpretation. This event dispersed material mostly over the adjacent ice sheet I c un, but the ash deposition involved also more inland areas of the EAP, as the occurrence of sporadic trachytic shards in the VK samples demonstrates. Infrequent ash layers of Antarctic derivation in long cores from the EAP have been already observed within the last four glacial-interglacial cycle ice series (e.g., Narcisi et al., 2010). We infer that the Antarctic volcanic plume entered into the polar vortex circulation and then rapidly reached the inner sectors of the Plateau. Based on the available data, it is unclear whether the plume from the AD 1259 Antarctic eruption dispersed particulate material onto the SP area. In the early tephra investigation by Palais et al. (1992), no trace of trachytic glass is reported for the Antarctic ice core. That tephra study however, was based upon the analysis of a handful of volcanic particles, representing a limitation for the detection of compositional heterogeneity and multiple fingerprints within individual horizons. Finally, similarly to other local eruptions, this Antarctic event likely delivered sulphate aerosols, but this is difficult to detect as it is combined with the coincidental broad signal peaking at AD 1259 related to long-range stratospheric transport and deposition of aerosols and generated during an extra-Antarctic source event (see discussion below). Note that examples of circacoeval multiple eruptions manifesting as a single volcanic signal are known in the Antarctic ice record (Cole-Dai and Mosley-Thompson, 1999; Cole-Dai et al., 2000). They represent tricky case studies for estimation of atmospheric aerosol loadings by related eruptions, with implications for assessment of the real impact on climate (e.g., Timmreck et al., 2009).

260 Our discovery of Antarctic-sourced tephra associated with the AD 1259 acidic deposition is 
signal (e.g., Sigl et al., 2015). Nevertheless it is not particularly surprising considering that Antarctic volcanoes from Victoria Land and Marie $-d$ Land show evidence of Holocenehistorical activity and ice cores drilled adjacent jolcanoes contain numerous locally derived discrete tephra layers, sometimes in the form of invisible horizons, as a result of persistent explosive activity (e.g., Kurbatov et al., 2006; Narcisi et al., 2012). In this respect, we point out that that the local eruption identified here does not correspond to the Antarctic event dated $1254 \pm 2 \mathrm{AD}$ that produced widespread tephra deposition over most of the Pacific-facing sector of Antarctica (Narcisi and Petit, 2018, and references therein). At TD and GV7 in fact this eruption occurs as both coarse visible ash and a sharp sulphate spike standing well above the background values and clearly preceding the AD 1259 volcanic peak (e.g., Narcisi et al., 2001; Severi et al., 2012). The newly identified event neither corresponds to the local eruption at AD 1261 detected as both volcanic sulphate deposition and a large particle concentration peak in the West Antarctic Ice Sheet (WAIS) Divide ice core (Koffman et al., 2013) that clearly follows the AD 1259 signal. Therefore, within a decade three distinct local events took place in the Antarctic mainland that left tangible fallout traces in the ice sheet. Such rapid succession of eruptions could be overlooked in low time resolution studies and instead needs to be carefully considered when addressing the attribution of Antarctic ice-core signals, as having implications for reconstructions of volcanic forcing.

280 The main sub-alkaline component of dacitic composition is genetically linked to subductionrelated volcanism. Differently from the trachytic glass, it is not straightforward to identify the source responsible for this tephra. The distant geographic location of the EAP with respect to subduction provinces provides no clues, and the tiny particle size of the volcanic material in the Central EAP ice suggests long-distance transport, thus enlarging the suite of potential source areas to be considered to the whole Southern Hemisphere and even beyond the Equator. Note in this respect that although not very frequently, ash produced in equatorialtropical volcanoes could have reached Antarctica during past eruptions, as in the case of Pinatubo $\left(15^{\circ} 14^{\prime} \mathrm{N}\right)$ tephra $(2-10 \mu \mathrm{m})$ identified in the 1993-94 snow layers at South Pole after the 1991 eruption (Cole-Dai et al., 1997). In the search for possible sources for the dacitic tephra, we therefore considered an extended inventory of volcanoes. A thorough discussion of this piece of our work is presented in Supplementary Material.

The recently discovered volcanic eruption of Samalas in the Indonesian Archipelago ( $8^{\circ} 33^{\prime} \mathrm{S}$ ) was suggested as the most probable source for the AD 1259 polar spike, due to its exceptional size (es+imated VEI and maximum plume height 7 and $43 \mathrm{~km}$, respectively) and appropriate date ( $\epsilon$ Lavigne et al., 2013; Vidal et al., 2015, 2016; Alloway et al., 2017). Indeed, we found/positive chemical match with Samalas products over all constituent elements considered (Figure $4 b$ ). Thus, the striking geochemical similarities between the Samalas glass and the ice core dacitic glass population along with the significant differences between the ice core glass and products from other potential sources (Figure S2) led us to conclude that our dacitic glass material was sourced from the Samalas AD 1257 eruption. Note that this volcanic material is also chemically coherent with glass shards formerly found in Greenland and SP ice cores (Palais et al., 1992) suggesting a common source eruption (Figure 4b). The cataclysmic AD 1257 Samalas explosive eruption clearly ranks among the greatest volcanic events of the Holocene. Once injected into the stratosphere up to about 40 $\mathrm{km}$ (Vidal et al., 2015), the Samalas tephra particles must have been transported poleward. Volcanic particles are supposed to settle in the lower stratosphere and accumulate just 
above the tropopause, similarly to ${ }^{10} \mathrm{Be}$ and sulphate. Then, when stratosphere/troposphere exchange of mass and chemical species ocr $\cdots$ above Antarctica, sedimentation of volcanic aerosols proceeds within the troposphere it the ice sheet surface. The whole process likely occurred on a timescale of 1-2 years, as indicated by the time shift between the eruption and deposition. Evidence for stratospheric transport of volcanic ash to Central EAP in association with strong explosive eruptions is not new. At Vostok, it has been observed (Delmonte et al., 2004) that small particles with modal values around 1.5-1.7 $\mu \mathrm{m}$ are generally associated stratospheric ash entering the troposphere during stratosphere/troposphere folding, jointly with sulphate and likely ${ }^{10} \mathrm{Be}$. We believe that in case of injection of large quantities of volcanic ash to great heights in the stratosphere also some relatively large particles can be transported in the stratosphere at great distance from the source, as suggested by presence of some large dacitic glasses in VK-14 sample.

A limited subset of glass analyses from a Vostok sample indicate distinctive high-silica rhyolitic composition with sub-alkaline affinity (Figure 4a). In the TAS diagram, this evolved component appears separated from the two main glass populations previously discussed, suggesting a different source. Note that this rhyolitic glass was not detected in the samples from the peripheral sites characterised by conspicuous deposition of locally-originated trachytic ash, suggesting that it is likely unrelated to the newly identified Antarctic eruption. Indeed, no such composition is known in the recent volcanic record from Antarctic centres (Dunbar et al., 2008; Narcisi et. al, 2012) and neither in the Samalas products (Vidal et al. 2015; Alloway et al., 2017). We therefore infer that this glass could be originated from a further distant event that contributed to the ice-core tephra. Interestingly, this interpretation could be in accordance with previous investigations in the WAIS Divide ice core that show that the stratospheric microparticle deposition during the year 1258 occurred in two pulses (Koffman et al., 2013), thus hinting for the possible contribution of two quasi-coeval tropical volcanic eruptions.

In the Southern Hemisphere, rhyolitic products related to subduction processes occur at some active Andean volcanoes and especially in the volcanic centres of New Zealand $\left(\sim 39^{\circ} \mathrm{S}\right.$, ca. $6000 \mathrm{~km}$ from the Vostol $\sim 2$ in direct line), whereas rarely were erupted from West Antarctic intraplate volcanoes. olitic ice-core glass shards display higher $\mathrm{K}_{2} \mathrm{O}$ contents compared to glasses of American itemporary volcanoes; they are also characterised by $\mathrm{CaO}$ and $\mathrm{FeO}$ contents $<1 \mathrm{wt} \%$, more typical of New Zealand rhyolitic glasses than of the Antarctic (Marie Byrd Land) ones found in the marine realm (Shane and Froggatt, 1992) (Figure S3). Although we are aware that some Andean centres may have been more geochemically evolved than $i t$ is currently rel $\square$ ented in literature data, none of the considered volcanoes appear compositionally/ iterent with our ice-core tephra subpopulation (Figure S3).

Considering the recent tephra record of New Zealand volcanoes, we observe that ice-core glass mimics the chemical composition of Kaharoa Tephra, which represents the only rhyolitic deposit during the last 1000 years in the region (Nairn et al., 2004, Lowe et al., 2013) (Figure S3). This plinian eruption however is precisely dated to AD $1314 \pm 12$ (Lowe et al., 2013, and references therein), thus is ca. 50 years younger than the polar spike (Lowe and Higham, 1998). Therefore, despite the geochemical similarities, the significant age difference 
located outside the Antarctic continent, remains undecided. Nevertheless, the New Zealand volcanic province represents the most frequently active rhyolitic zone on Earth (e.g., Smith et al., 2005) and is a suitable source of tephra in Antarctica, despite only one New Zealand tephra layer in Antarctic ice has been identified so far (Dunbar et al., 2017). Our intriguing finding could hopefully provide a hint for future investigations.

\subsection{Implications}

Volcanic eruptions are drivers of transient weather and climate disturbances (e.g., Robock, 2000). The possible climate-forcing produced by the Samalas event, the most powerful eruption of the last millennium, has been addressed in several papers using various proxy archives and historical documents, along with estimate of the release of gas during the eruption based upon an independent geochemical approach. The volatile emissions standing as the greatest volcanogenic gas injection of the last few millennia were enough to produce global cooling (Vidal et al., 2016). Indeed, considerable environmental and social postvolcanic effects were reconstructed that along the Central Indonesian archipelago affected also vast regions of Europe (Guillet et al., 2107; Alloway et al., 2017). According to Gennaretti et al. (2014), tree-ring-based temperature reconstruction from northeastern North America displays an abrupt cooling regime shift that chronologically coincides with the occurrence of a series of eruptions centred around the AD 1257 Samalas event suggesting volcanic impact on the local forests and ice-caps. Moreover, indirect geological sources show occurrence of an El Nir re event in the Americas and SE Asia in the year after the mega-eruption that suggests/causal connection between the volcanic event and the climate anomaly (EmileGeay et al., 2008; Alloway et al., 2017). In the Antarctic record, the $13^{\text {th }}$ century appears exceptionally rich in conspicuous volcanic signals, with the AD 1259 being the most prominent (e.g., Cole-Dai et al., 2000). Possible effects of volcanic activity around the date of 1259 have been invoked also for high southern latitudes, but the data are still very sparse. Using a combination of firn/ice core records, Frezzotti et al. (2013) identified middle $13^{\text {th }}$ century as the onset of a 50yrs-long period of negative surface mass balance of the Antarctic ice she the continental scale. This pattern could be related to solar irradiance with other factors, $\sim$ - volcanic forcing, superimposing (Frezzotti et al., 2013).

Results of ice-core tephra studies presented here and elsewhere (Koffman et al., 2013; Narcisi and Petit, 2018, and refe $\square$ es therein) collectively have shown for the first time that three distinct Antarctic eruptio, $>$ wok place in the time span of a decade between AD $1254 \pm 2$ and AD 1261. These eruptions produced deposition of tephra blanket and atmospheric sulphate aerosols onto the polar ice sheet. In the ice volcanic record local eruptions typically emitting only tropospheric sulphate are represented by strong but short-lived residence times of aerosols in the atmosphere (e.g., Castellano et al., 2005). This pattern suggests that such individual events most likely are incapable of significant large-scale climatic impact. However, here we raise 1 luestion about the potential consequences of this closely spaced local eruption sequencquccurred in association with the tropical Samalas eruption, on the Antarctic climate and environment. Note that owing to the close proximity to the source region the local forcing would be exerted through both the radiative impacts of gas and particulate aerosols and the reduction in ice surface albedo produced by repeated extensive tephra deposition. With respect to the latter factor, recent estimations have shown the significance of volcanic ash deposition onto snow/ice even from mid-sized eruptions at high- 
latitudes to alter surface reflectivity and ennance glacier melting (e.g., Dadic et al., 2013; Young et al., 2014; Muschitiello et al., 2017). Given the continuous sustained explosive activity of the Antarctic volcanoes with related large production of tephra and consequent dispersal over the Plateau due to favourable atmospheric conditions (e.g., Scarchilli et al., 2011), we believe that the potential role of forcing caused by locally-derived ash deposits should not be neglected in Antarctic palaeoclimate reconstructions. This factor deserves further more specific investigation in future research.

With respect to sulphate emission, unfortunately the available data currently do not permit to distinguish between the contribution to the aerosol deposition from the Samalas event and the AD 1259 local Antarctic eruption. These limitations notwithstanding, at this stage we can remark that in Antarctica two distinct volcanic forcings (one tropical and the other of high southern-latitude) may be superimposed around the date of 1259. In conclusion, our results add complexity to interpretation of volcanic aerosol yields from polar records and could have implications for more reliable climate model simulations for the pre-instrumental period (Schneider et al., 2009; Stoffel et al., 2015, and references therein).

\section{Conclusions}

Non-visible tephra deposits trapped within polar snow and ice represent precious chronostratigraphic tools. When the material is found associated with a prominent acidic signal, firm attribution to specific eruptions can be given with implications for climate forcing reconstructions. However, tephra detection and fingerprinting iuch remote locations is often problematic. We successfully used four cores collected froi yuifferent sites in the EAP to demonstrate extensive deposition of volcanic dust on the ice/sheet coeval with the large acidity peak at AD 1259, a key time stratigraphic horizon of inter-hemispheric significance. Our compelling data show that the material displays different characteristics from site to site. Geochemical fingerprinting of tephra, obtained with a grain-specific methodology, indicates that altogether multiple distinct explosive events have contributed to the ice core ash deposition, i.e. a newly-identified Antarctic eruption in AD 1259, the great AD 1257 eruption of Samalas, and a further eruption likely occurred somewhere outside Antarctica. Indeed, spatial variations reflecting different atmospheri? culation patterns over the EAP were significant in the volcanic deposition on the ice sheet and should not be discounted in order to obtain sound source attribution of volcanic signals in polar sequences. We therefore underline the need of detailed studies based upon a multi-site and parameter approach as well as a large number of chemical analyses for capturing complexities inside tephra. Our results of the chemical composition of hundreds of microscopic particles confirm the inferred linkage of the Antarctic ice signal with the Samalas tropical eruption occurred in AD 1257, but also provide evidence for a coincidental cluster of local explosive events, so far not adequately considered in climate reconstructions derived by ice-core volcanic aerosol records. Local activity instead was important in shaping the Antarctic volcanic record and should be regarded as an agent of potential regional disturbances, not least through dispersion of ash over large areas with consequent radiative impact. We emphasise the potential of tephra investigations with respect to traditional measurements of aerosol concentrations in ice also for identifying superimposition of distinct contemporary events at a single site. Our findings also contribute to a more complete reconstruction of the history of volcanic activity in the Antarctic region. 


\section{Aknowledgements}

We thank D.J. Lowe (University of Waikato) for his useful advice on New Zealand 444 tephrochronology, N. Metrich and J.-C. Komorowski (Institut de Physique du Globe de Paris) 445 for providing tephra samples from the Samalas deposits, C. Rado for drilling operations at 446 Vostok, and E. Gautier (IGE, Grenoble) for DC ice sample selection. The Vostok ice core was obtained during 1991-92 field season through the Russian US French collaboration on ice cores with the support from the Soviet-Russian Antarctic Expedition, the National Science Foundation and the French Polar Institute. This works contributes to TALos Dome Ice CorE (TALDICE), a joint European programme lead by Italy and funded by national contributions from Italy, France, Germany, Switzerland and the United Kingdom, that was aimed at retrieving an ice core reaching back through the previous two interglacials (about 250,000 years). This is TALDICE publication no. XXx.. The GV7 drilling project, carried out in cooperation with KOPRI (Korea Polar Research Institute), was financially supported by the MIUR (Italian Ministry of University and Research)-PNRA (Italian Antarctic Research Programme) program through the IPICS-2kyr-It project. Author Contributions: B.N. and J.R.P. conceived this study. J.R.P. conducted ice-core sample processing grain-size analysis, and preliminary microprobe work. B.N. conducted tephra analysis, interpreted the results, and wrote most of the manuscript. V.B. was responsible for microprobe work. B.D. interpreted grain-size data and significantly contributed to the writing of the text. J.S. collaborated in the discussion of the experimental results. 
Figure 1. (a) AD 1259 signal (as sulphate in $\mathrm{mg} / \mathrm{L}$, or electrical conductivity, ECM, in arbitrary units) in the studied Antarctic cores. TALDICE sulphate profile redrawn from Severi et al. (2012), GV7 sulphate profile courtesy of R. Nardin. Also shown is the position of samples analysed for grain size and geochemistry (grey shaded blocks). The dashed line indicates 'bag' section limit and/or core break. (b) Map of Antarctica with location of the ice cores and main Quaternary volcanoes in Victoria Land (e.g., Mt. Erebus, Mt. Melbourne and The Pleiades) and in Marie Byrd Land, West Antarctica (e.g., Mt. Takahe and Mt. Berlin).

Figure 2. Mass-size distributions (Relative Units, R.U., \%) of samples analysed for geochemistry. (A): Central EAP samples from Dome C (DC 71-a) and Vostok BH6 (VK-30-14 and VK-30-16) ice cores. (B): TD samples 87-1, 86-4, 86-3, 86-2 from the base to the top of the volcanic sulphate spike.

Figure 3. Scanning electron microphotographs of volcanic glass particles from a, DC-71a; b-c, VK-14; d-e, TD-87-1; f, TD-86-4.

Figure 4. (a) Total alkali-silica (TAS) classification diagram and alkaline/sub-alkaline division line (Rickwood, 1989, and references therein) showing the normalised analyses of ice-core shards. $\mathrm{Ph}=$ Phonolite, $\mathrm{An}=$ Andesite, $\mathrm{T}=$ Trachyte, $\mathrm{D}=$ Dacite, $\mathrm{Rh}=$ Rhyolite. $\mathrm{In}$ the inset the TAS diagram with envelopes for the three glass compositional sub-populations is illustrated. (b) The TAS classification diagram as above showing the whole data set (in grey-scale) compared with glass geochemical analyses for the most likely correlatives (data from Alloway et al., 2017; Narcisi et al., 2012, 2016, 2017; Palais et al., 1992). Geochemical comparison with further potential sources is provided in Supplementary Material.

Figure 5. Total alkali-silica (TAS) classification diagram and alkaline/sub-alkaline division line (Rickwood, 1989, and references therein) for the normalised analyses of ice-core shards in the four TD samples. Data of pertinent samples are superimposed upon the whole data set (in grey-scale) for comparative purposes. $\mathrm{Ph}=$ Phonolite, $\mathrm{An}=$ Andesite, $\mathrm{T}=$ Trachyte, $\mathrm{D}=$ Dacite, $\mathrm{Rh}=$ Rhyolite. For the stratigraphic position of samples with respect to the AD 1259 ice-core volcanic signal see Fig. 1.

\section{Captions for Supplementary Tables and Figures}

Table S1. Location and characteristics of the studied ice cores.

Table S2. Composition of reference glasses and Samalas samples measured at different analytical conditions.

Table S3. Representative major element composition of individual glass shards determined by electron microprobe analysis. Values are given in weight \% oxide and are normalised to $100 \%$. Total iron is expressed as FeO. MnO not determined. Glass populations as defined in the main text.

Figure S1. World map showing the location of Antarctic ice core sites (blue dots) and of 
503 selected volcanic sources considered in the text (red triangles). Letters for sources are as 504 follows. CH, Chaitén; EC, El Chichón; HU, Hudson; MBL, Marie Byrd Land; NZ, New Zealand; 505 PCC, Puyehue-Cordon Caulle; QU, Quilotoa; SM, Samalas; SSh, South Shetland Islands; SSI, 506 South Sandwich Islands; VL, Victoria Land.

507 Figure S2. Monte Carlo simulation of the interaction and emission volumes of X-rays at $10 \mathrm{kV}$ 508 for $\mathrm{Na}-\mathrm{K} \otimes$ in Na-Si rich glass considered as A) common polished sample and B) small $1 \times 1 \mu \mathrm{m}$ 509 particle placed on the C-glue. The blue lines show the electron trajectory outside the particle.

511 Figure S3. Major element biplots for the analysed ice-core shards (in grey-scale) compared 512 with glass geochemical analyses for selected potential sources and counterparts (data from 513 Moreno et al., 2015; Fontijn et al., 2016; Nairn et al., 2004; Kratzmann et al., 2009; Moreno et 514 al., 2015; Nooren et al., 2017; Stewart and Castro, 2016; Shane and Froggatt, 1992). Location 515 of considered source volcanoes is shown in Supplementary Figure S1. 
Alloway, B.V., Andreastuti, S., Setiawan, R., Miksic, J., Hua, Q. (2017). Archaeological implications of a widespread 13th Century tephra marker across the central Indonesian Archipelago. Quaternary Science Reviews 155, 86-99, https://doi.org/10.1016/j.quascirev.2016.11.020

Barbante, C., Kehrwald, N. M., Marianelli, P., Vinther, B. M., Steffensen, J. P., Cozzi, G., Hammer, C. U., Clausen, H. B., Siggaard-Andersen, M.-L. (2013). Greenland ice core evidence of the 79 AD Vesuvius eruption. Climate of the Past 9, 1221-1232, https://doi.org/10.5194/cp-9-1221-2013

Baroni, M., Savarino, J., Cole-Dai, J., Rai, V.K., Thiemens, M. H. (2008). Anomalous sulfur isotope compositions of volcanic sulfate over the last millennium in Antarctic ice cores. Journal of Geophysical Research: Atmospheres 113, D20, 2156-2202, DOI: 10.1029/2008JD010185

Castellano, E., Becagli S., Hansson M., Hutterli M., Petit J.R., Rampino M.R., Severi M., Steffensen J.P., Traversi R., Udisti R. (2005). Holocene volcanic history as recorded in the sulfate stratigraphy of the European Project for Ice Coring in Antarctica Dome C (EDC96) ice core. Journal of Geophysical Research 110, D06114, doi:10.1029/2004JD005259

Cole-Dai, J., Mosley-Thompson, E., Thompson, L.G. (1997). Quantifying the Pinatubo volcanic signal in south polar snow. Geophysical Research Letters 24, 2679-2682.

Cole-Dai, J., Mosley-Thompson, E. (1999). The Pinatubo eruption in South Pole snow and its potential value to ice-core paleovolcanic records. Annals of Glaciology 29, 99-105. doi:10.3189/172756499781821319

Cole-Dai, J., Mosley-Thompson, E., Wight, S. P., Thompson, L.G. (2000). A 4100-year record of explosive volcanism from an East Antarctica ice core. Journal of Geophysical Research 105(D19), 24431-24441, doi:10.1029/2000JD900254

Dadic, R., Mullen, P.C., Schneebeli, M., Brandt, R.E., Warren, S.G. (2013). Effects of bubbles, cracks, and volcanic tephra on the spectral albedo of bare ice near the Transantarctic Mountains: Implications for sea glaciers on Snowball Earth. Journal of Geophysical Research: Earth Surface, 118, 1658-1676, doi:10.1002/jgrf.20098

Delmas, R.J., Kirchner, S., Palais, J.M., Petit, J.R. (1992). 1000 years of explosive volcanism recorded at the South Pole. Tellus 44B, 335-350.

Delmonte, B., Petit, J.R., Maggi, V. (2002). Glacial to Holocene implications of the new 27000-year dust record

Delmonte, B., Petit, J.R., Andersen, K.K., Basile-Doelsch, I., Maggi, V., Lipenkov, V.Ya (2004). Dust size evidence for opposite regional atmospheric circulation changes over east Antarctica during the last climatic transition. Climate Dynamics 23 (3-4), 427-438.

Delmonte, B., Petit, J.R., Krinner, G., Maggi, V., Jouzel, J., Udisti, R. (2005). Ice core evidence for secular variability and 200-year dipolar oscillations in atmospheric circulation over East Antarctica during the Holocene. Climate Dynamics, 24 (6), 641-654.

Delmonte, B., Baroni, C., Andersson, P.S., Narcisi, B., Salvatore, M.C., Petit, J.R., Scarchilli, C., Frezzotti, M., Albani, S., Maggi, V. (2013). Modern and Holocene aeolian dust variability from Talos Dome (Northern Victoria Land) to the interior of the Antarctic ice sheet. Quaternary Science Reviews 64, 76-89, http://dx.doi.org/10.1016/j.quascirev.2012.11.033 
Dunbar, N.W., Iverson, N.A., Van Eaton, A.R., Sigl, M., Alloway, B.V., Kurbatov, A.V., Mastin, L.G., Mc Donnell, J.R., Wilson, C.J.N., (2017). New Zealand supereruption provides time marker for the Last Glacial Maximum in Antarctica. Scientific Reports 7, Article number: 12238, doi: 10.1038/s41598-017-11758-0

Emile-Geay, J., Seager, R., Cane, M.A., Cook, E.R., Haug, G.H. (2008). Volcanoes and ENSO over the past millennium. Journal of Climate 21, 3134-3148.

Frezzotti, M., Scarchilli, C., Becagli, S., Proposito, M., Urbini, S. (2013). A synthesis of the Antarctic surface mass balance during the last $800 \mathrm{yr}$. The Cryosphere 7, 303-319, https://doi.org/10.5194/tc-7-303-2013

Gennaretti, F., Arseneault, D., Nicault, A., Luc Perreault L., Bégin, Y. (2014). Volcano-induced regime shifts in millennial tree-ring chronologies from northeastern North America. Proceedings of the National Academy of Sciences 111 (28) 10077-10082; https://doi.org/10.1073/pnas.1324220111

Guillet, S., Corona, C., Stoffel, M., Khodri, M., Lavigne, F., Ortega, P. et al. (2017). Climate response to the Samalas volcanic eruption in 1257 revealed by proxy records. Nature Geoscience 10,123-128.

Hammer, C.U. (1980). Acidity of polar ice cores in relation to absolute dating, past volcanism, and radio-echoes. Journal of Glaciology 25, 359-372, https://doi.org/10.3189/S0022143000015227

Koffman, B.G. Kreutz K.J., Kurbatov, A.V., Dunbar, N.W. (2013). Impact of known local and tropical volcanic eruptions of the past millennium on the WAIS Divide microparticle record. Geophysical Research Letters 40, 1-5, doi:10.1002/grl.50822

Kurbatov, A.V., Zielinski, G.A., Dunbar, N.W., Mayewski, P.A., Meyerson, E.A., Sneed, S.B., Taylor, K.C. (2006). A 12,000 year record of explosive volcanism in the Siple Dome Ice Core, West Antarctica. Journal of Geophysical Research 111, D12307, doi:10.1029/2005JD006072

Iverson, N.A., Kalteyer, D., Dunbar, N.W., Kurbatov, A.V., Yates, M. (2017). Advancements and best practices for analysis and correlation of tephra and cryptotephra in ice. Quaternary Geochronology 40, 45-55, https://doi.org/10.1016/j.quageo.2016.09.008

Langway, C.C., Clausen, H., Hammer, C. (1988). An inter-hemispheric volcanic time-marker in ice cores from Greenland and Antarctica. 『Annals of Glaciology 10, 102-108.

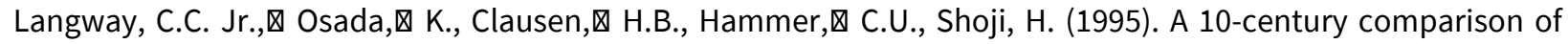
prominent bipolar volcanic events in ice cores. Journal of Geophysical Research 100 (D8), 16241-16247.

Lavigne, F., Degeai, J.-P., Komorowski, J.-C., Guillet, S., Robert, V., Lahitte, P., Oppenheimer, C., Stoffel, M., Vidal, C.M., Surono, Pratomo, I., Wassmer, P., Hajdas, I., Sri Hadmoko, D., de Belizal, D. (2013). Source of the great A.D. 1257 mystery eruption unveiled, Salamas volcano, Rinjani Volcanic Complex, Indonesia. Proceedings of the National Academy of Sciences 110 (42) 16742-16747, https://doi.org/10.1073/pnas.1307520110

Lowe, D.J., 2011. Tephrochronology and its application: a review. Quaternary Geochronology 6,107-153, http://dx.doi.org/10.1016/j.quageo.2010.08.003

Lowe, D.J., Blaauw, M., Hogg, A.G., Newnham, R.M. (2013). Ages of 24 widespread tephras erupted since 30,000 years ago in New Zealand, with re-evaluation of the timing and palaeoclimatic implications of the Lateglacial cool episode recorded at Kaipo bog. Quaternary Science Reviews 74, 170-194.

Lowe, D.J., Higham, T.F.G. (1998). Hit-or-myth? Linking a 1259 AD acid spike with an Okataina eruption. Antiquity $72,427-431$.

Mann, M.E., Zhang, Z., Rutherford, S., Bradley, R.S., Hughes, M.K., Shindell, D., Ammann, C., Faluvegi, G., Ni, F. (2009). Global signatures and dynamical origins of the Little Ice Age and Medieval Climate Anomaly. Science 326, 1256-1260, DOI: 10.1126/science.1177303 
Masson-Delmotte, V., Buiron, D., Ekaykin, A., Frezzotti, M., Gallée, H., Jouzel, J., Krinner, G., Landais, A., Motoyama, H., Oerter, H., Pol, K., Pollard, D., Ritz, C., Schlosser, E., Sime, L.C., Sodemann, H., Stenni, B., Uemura, R., Vimeux, F. (2011). A comparison of the present and last interglacial periods in six Antarctic ice cores. Climate of the Past 7, 397-423.

Muschitiello, F., Pausata, F.S.R., Lea, J.M., Mair, D.W.F., Wohlfarth, B. (2017). Enhanced ice sheet melting driven by volcanic eruptions during the last deglaciation. Nature Communications 8, Article number: 1020, DOI: 10.1038/s41467-017-01273-1

Nairn, I.A, Shane, P.R, Cole, J.W, Leonard, G.J, Self, S., Pearson, N. (2004). Rhyolite magma processes of the AD 1315 Kaharoa eruption episode, Tarawera volcano, New Zealand. Journal of Volcanology and Geothermal Research 131, 265-294, https://doi.org/10.1016/S0377-0273(03)00381-0

Narcisi, B., Proposito, M. Frezzotti, M. (2001). Ice record of a 13th century explosive volcanic eruption in northern Victoria Land, East Antarctica. Antarctic Science 13, 174-181.

Narcisi, B., Petit, J.R., Delmonte, B., Basile-Doelsch, I., Maggi, V. (2005). Characteristics and sources of tephra layers in the EPICA-Dome $\mathrm{C}$ ice record (East Antarctica): implications for past atmospheric circulation and ice core stratigraphic correlations. Earth and Planetary Science Letters 239, 253-265.

Narcisi, B., Petit, J.R., Delmonte, B. (2010). Extended East Antarctic ice core tephrostratigraphy. Quaternary Science Reviews 29, 21-27.

Narcisi, B., Petit, J.R., Delmonte, B., Scarchilli, C., Stenni, B. (2012). A 16,000-yr tephra framework for the Antarctic ice sheet: a contribution from the new Talos Dome core. Quaternary Science Reviews 49, 52-63.

Narcisi, B., Petit, J.R., Langone, A., Stenni, B. (2016). A new Eemian record of Antarctic tephra layers retrieved from the Talos Dome ice core (Northern Victoria Land). Global and Planetary Change 137, 69-78, http://dx.doi.org/10.1016/j.gloplacha.2015. 12.016

Narcisi, B., Petit, J.R., Langone, A., 2017. Last glacial tephra layers in the Talos Dome ice core (peripheral East Antarctic Plateau), with implications for chronostratigraphic correlations and regional volcanic history. Quaternary Science Reviews, 165, 111-126.

Narcisi, B., Petit, J.R. (2018). Englacial tephras of East Antarctica. In J. Smellie, K. Panter, A. Geyer (eds), Volcanism in Antarctica: 200 Million Years of Subduction, Rifting and Continental Break-Up. Geological Society, London, Memoirs, in press.

Oppenheimer, C. (2003). Ice core and palaeoclimatic evidence for the timing and nature of the great mid-13th century volcanic eruption. International Journal of Climatology 23, 417-426, doi:10.1002/joc.891

Palais, J.M, Germani, M.S., Zielinski, G.A. (1992). Interhemispheric transport of volcanic ash from a 1259 A.D. volcanic eruption to the Greenland and Antarctic ice sheets. Geophysical Research Letters 19(8), 801-804.

Petit, J.R., Narcisi, B., Batanova, V.G., Savarino, J., Komorowski, J.C., Michel, A., Metrich, N., Besson, P., Vidal, C., Sobolev, A.V. (2016). Identifying the AD 1257 Salamas volcanic event from micron-size tephra composition in two East Antarctic ice cores. Geophysical Research Abstracts, 18, EGU2016-5191.

Ponomareva, V., Portnyagin, M., Davies, S.M. (2015). Tephra without borders: far-reaching clues into past

Rickwood, P.C. (1989). Boundary lines within petrologic diagrams which uses oxides of major and minor elements, Lithos 22, 247-263.

Robock, A. (2000). Volcanic eruptions and climate. Reviews of Geophysics 38, 191-219, doi:10.1029/1998RG000054 
Scarchilli, C., Frezzotti, M., Ruti, P.M. (2011). Snow precipitation at four ice core sites in East Antarctica: provenance, seasonality and blocking factors. Climate Dynamics 37, 2107-2125, http://dx.doi.org/10.1007/s00382-010-0946-4.

Schneider, D. P., Ammann C. M., Otto-Bliesner B.L., Kaufman, D.S. (2009). Climate response to large, highlatitude and low-latitude volcanic eruptions in the Community Climate System Model. Journal of Geophysical Research 114, D15101, doi:10.1029/2008JD011222

Severi, M., Udisti, R., Becagli, S., Stenni, B., Traversi, R. (2012). Volcanic synchronisation of the EPICA-DC and TALDICE ice cores for the last $42 \mathrm{kyr}$ BP. Climate of the Past 8, 509-517.

Shane, P.A.R., Froggatt, P.C. (1992). Composition of widespread volcanic glass in deep-sea sediments of the Southern Pacific Ocean: an Antarctic source inferred. Bulletin of Volcanology 54, 595-601.

Sigl, M., McConnell, J.R., Toohey, M., Curran, M., Das, S.B., Isaksson, E., Kawamura, K., Kipfstuhl, S., Krüger, K., Layman, L., Maselli, O.J., Motizuki, Y., Motoyama, H., Pasteris, D.R., Severi, M., (2014). Insights from Antarctica on volcanic forcing during the Common Era. Nature Climate Change 4, 693-697, http://dx.doi.org/10.1038/nclimate2293

Sigl, M., Winstrup, M., McConnell, J.R., Welten, K.C., Plunkett, G., Ludlow, F., Büntgen, U., Caffee, M., Chellman, N., Dahl-Jensen, D., Fischer, H., Kipfstuhl, S., Kostick, C., Maselli, O.J., Mekhaldi, F., Mulvaney, R., Muscheler, R., Pasteris, D.R., Pilcher, J.R., Salzer, M., Schüpbach, S., Steffensen, J.P., Vinther, B.M., Woodruff, T.E. (2015). Timing and climate forcing of volcanic eruptions for the past 2,500 years. Nature 523, 543-549. doi:10.1038/nature14565

Smith, V.C., Shane, P., Nairn, I.A. (2005). Trends in rhyolite geochemistry, mineralogy, and magma storage during the last $50 \mathrm{kyr}$ at Okataina and Taupo volcanic centres, Taupo Volcanic Zone, New Zealand. Journal of Volcanology and Geothermal Research 148 (3-4), 372-406, https://doi.org/10.1016/j.jvolgeores.2005.05.005

Stoffel, M., Khodri, M., Corona, C., Guillet, S., Poulain, V. Bekki, S., Guiot J., Luckman B.H., Oppenheimer C., Lebas, $₫$ N., Beniston M., Masson-Delmotte V. (2015). Estimates of volcanic-induced cooling in the Northern Hemisphere over the past 1,500 years. Nature Geoscience 8, 784-788, DOI: 10.1038/NGEO2526

Stothers, R.B. (2000). Climatic and demographic consequences of the massive volcanic eruption of 1258 . Climatic Change 45, 361-374.

Svensson, A., Bigler, M., Blunier, T., Clausen, H. B., Dahl-Jensen, D., Fischer, H., Fujita, S., Goto-Azuma, K., Johnsen, S. J., Kawamura, K., Kipfstuhl, S., Kohno, M., Parrenin, F., Popp, T., Rasmussen, S. O., Schwander, J., Seierstad, I., Severi, M., Steffensen, J. P., Udisti, R., Uemura, R., Vallelonga, P., Vinther, B. M., Wegner, A., Wilhelms, F., Winstrup, M. (2013). Direct linking of Greenland and Antarctic ice cores at the Toba eruption (74 ka BP). Climate of the Past 9, 749-766, https://doi.org/10.5194/cp-9-749-2013

Timmreck, C., Lorenz S.J., Crowley T.J., Kinne S., Raddatz T.J., Thomas M.A., Jungclaus J.H. (2009). Limited temperature response to the very large AD 1258 volcanic eruption. Geophysical Research Letters 36, L21708, doi:10.1029/2009GL040083

Vidal, C.M., Komorowski, J.-C., Metrich, N., Pratomo, I., Kartadinata, N., Prambada, O., Michel, A., Carazzo, G., Lavigne, F., Rodysill, J., Fontijn, K., Surono, 2015. Dynamics of the major plinian eruption of Samalas in 1257 A.D. (Lombok, Indonesia). Bulletin of Volcanology 77, 73. http://dx.doi.org/10.1007/s00445-015-0960-9 Common Era. Scientific Reports 6, Article number: 34868, DOI: 10.1038/srep34868 
694 Yalcin, K., Wake, C.P., Kreutz, K.J., Germani, M.S., Whitlow, S.I. (2006). Ice core evidence for a second volcanic 695 eruption around 1809 in the Northern Hemisphere. Geophysical Research Letters 33, L14706, 696 doi:10.1029/2006GL026013

697 Young, C. L., Sokolik, I.N., Flanner, M.G., Dufek, J. (2014). Surface radiative impacts of ash deposits from the 2009 698 eruption of Redoubt volcano, Journal of Geophysical Research Atmosphere 119, 11387-11397, 699 doi:10.1002/2014JD021949

700 Zielinski, G.A. (1995). Stratospheric loading and optical depth estimates of explosive volcanism over the last 7012100 years derived from the GISP2 Greenland ice core. Journal of Geophysical Research 100, 20937-20955. DOI: $702 \quad 10.1029 / 95 J D 01751$

703 Zielinski, G.A., Dibb, J.E., Yang, Q., Mayewski, P.A., Whitlow, S., Twickler, M.S., Germani, M.S. (1997). Assessment 704 of the record of the 1982 El Chichón eruption as preserved in Greenland snow. Journal of Geophysical 705 Research 102 (D25), 30,031-30,045, doi:10.1029/97JD01574 
(a)

Central Plateau

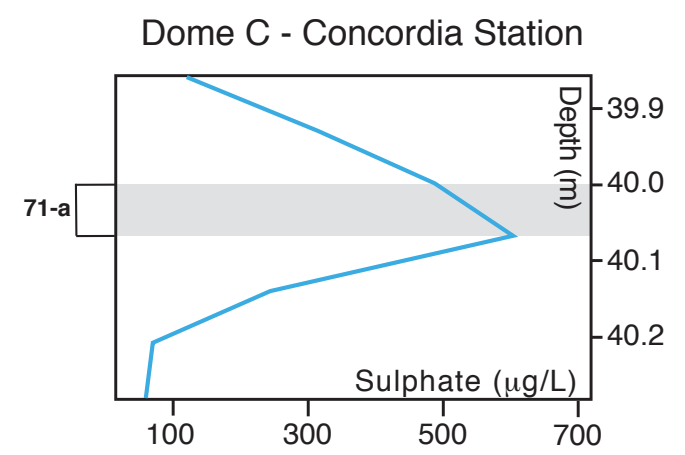

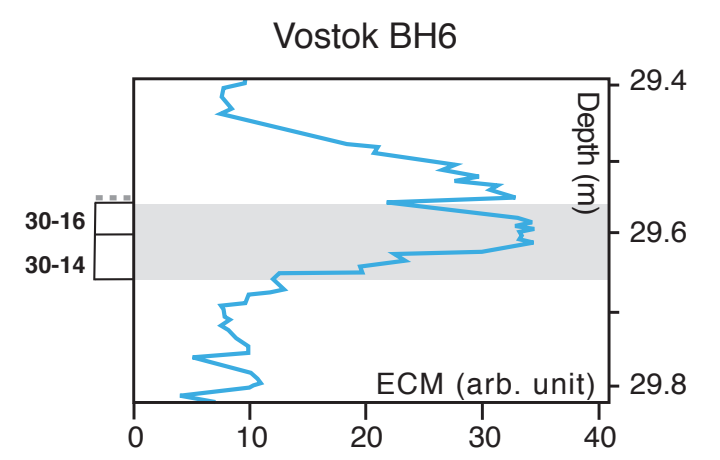

Peripheral Plateau
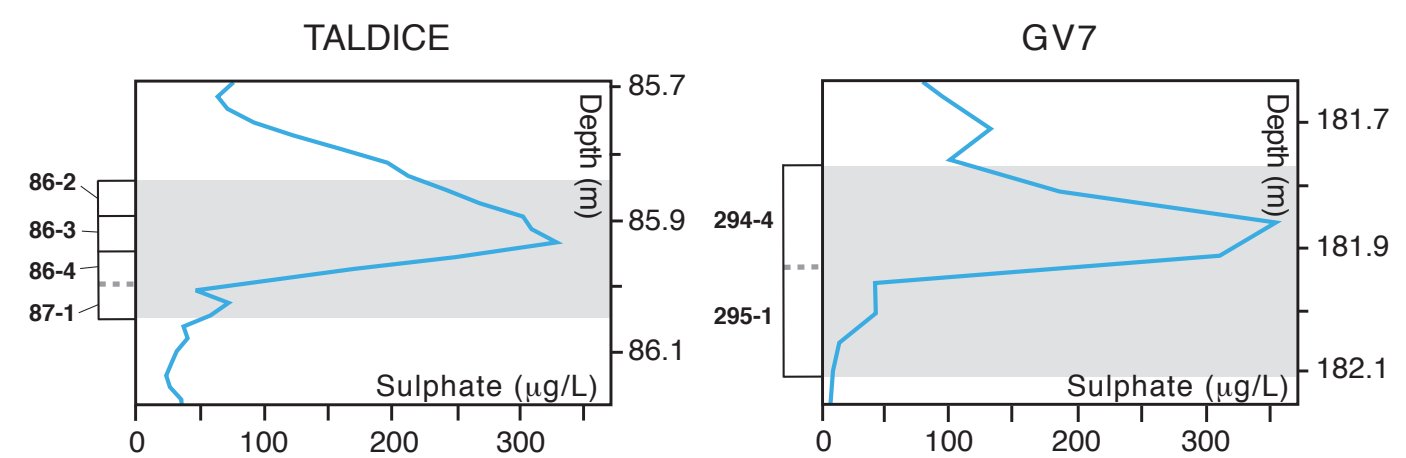

(b)

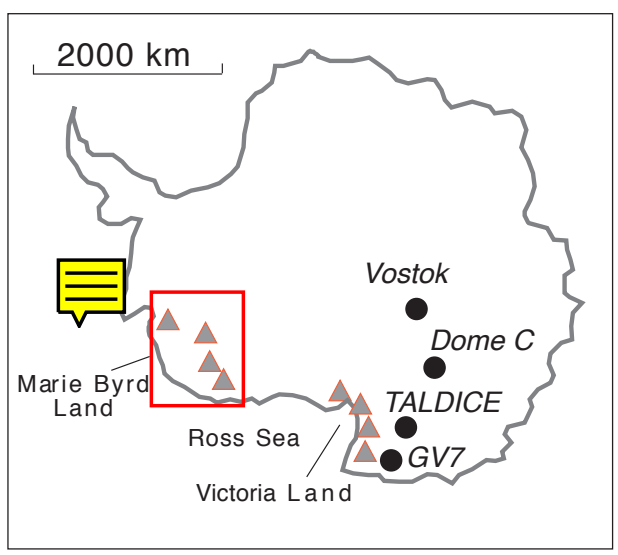



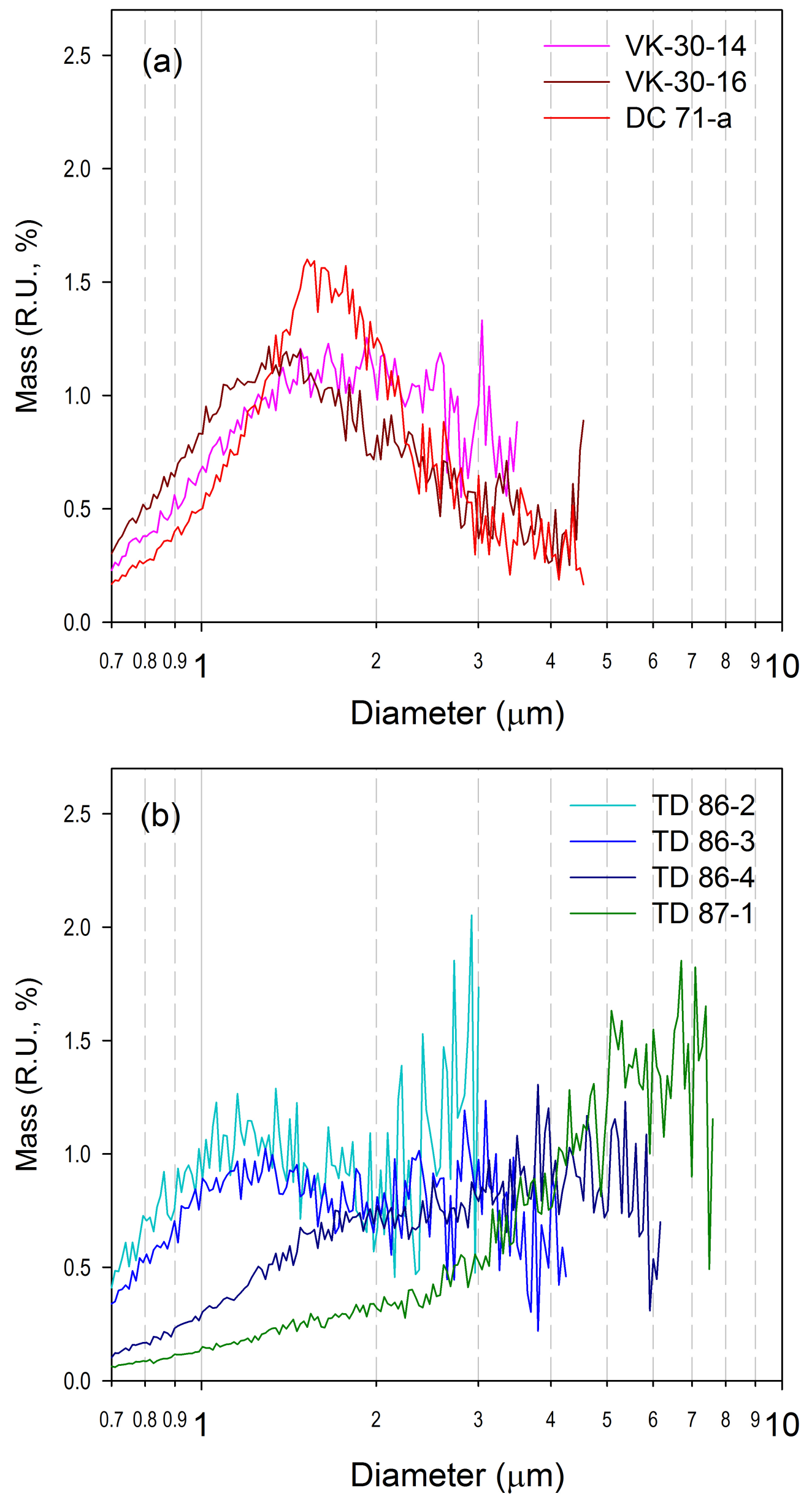

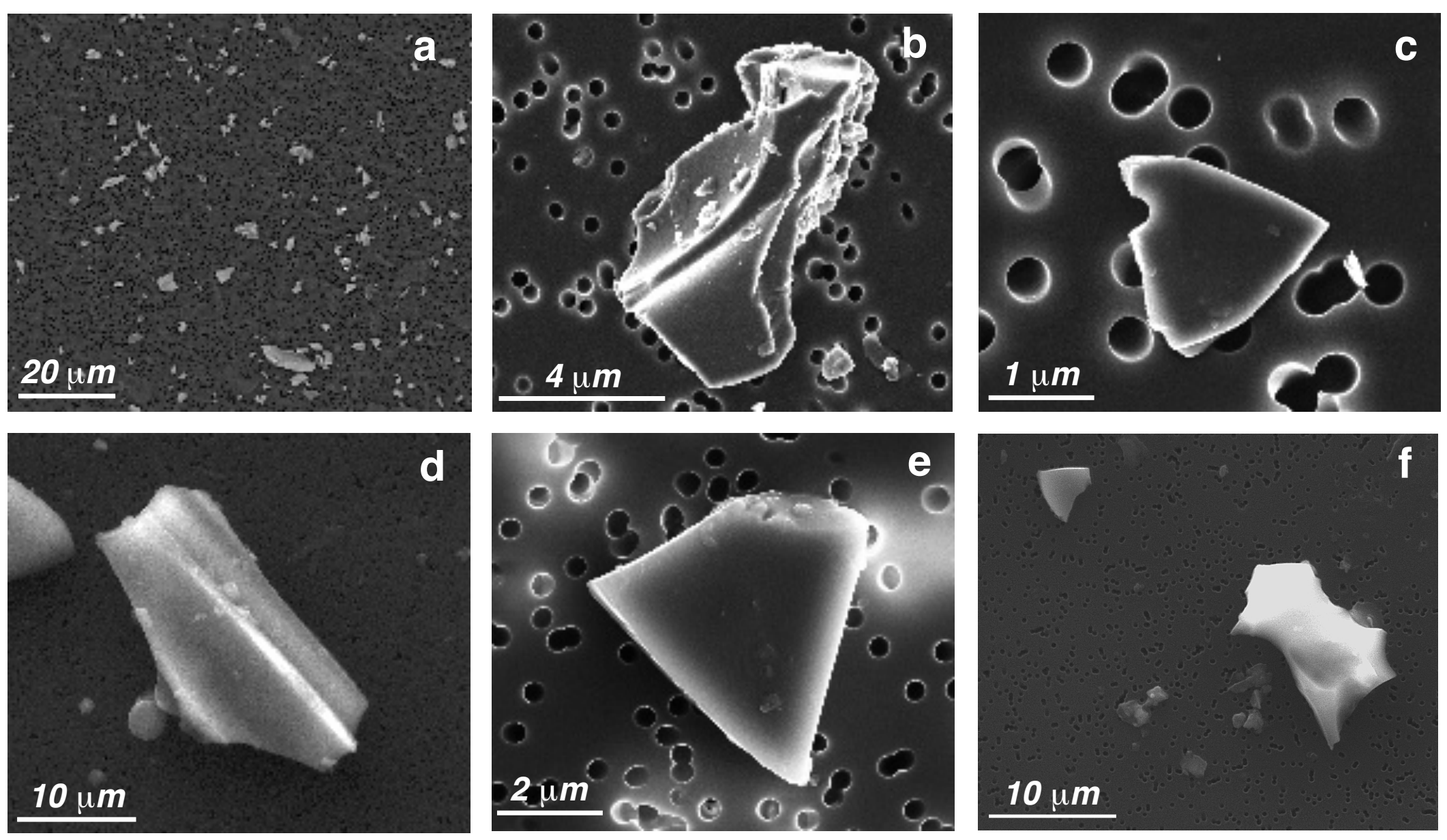

Fig. 3. Scanning electron microphotographs of volcanic glass particles from a, DC-71a; b-c, VK-14; d-e, TD87-1; f, TD86-4. 
(a)

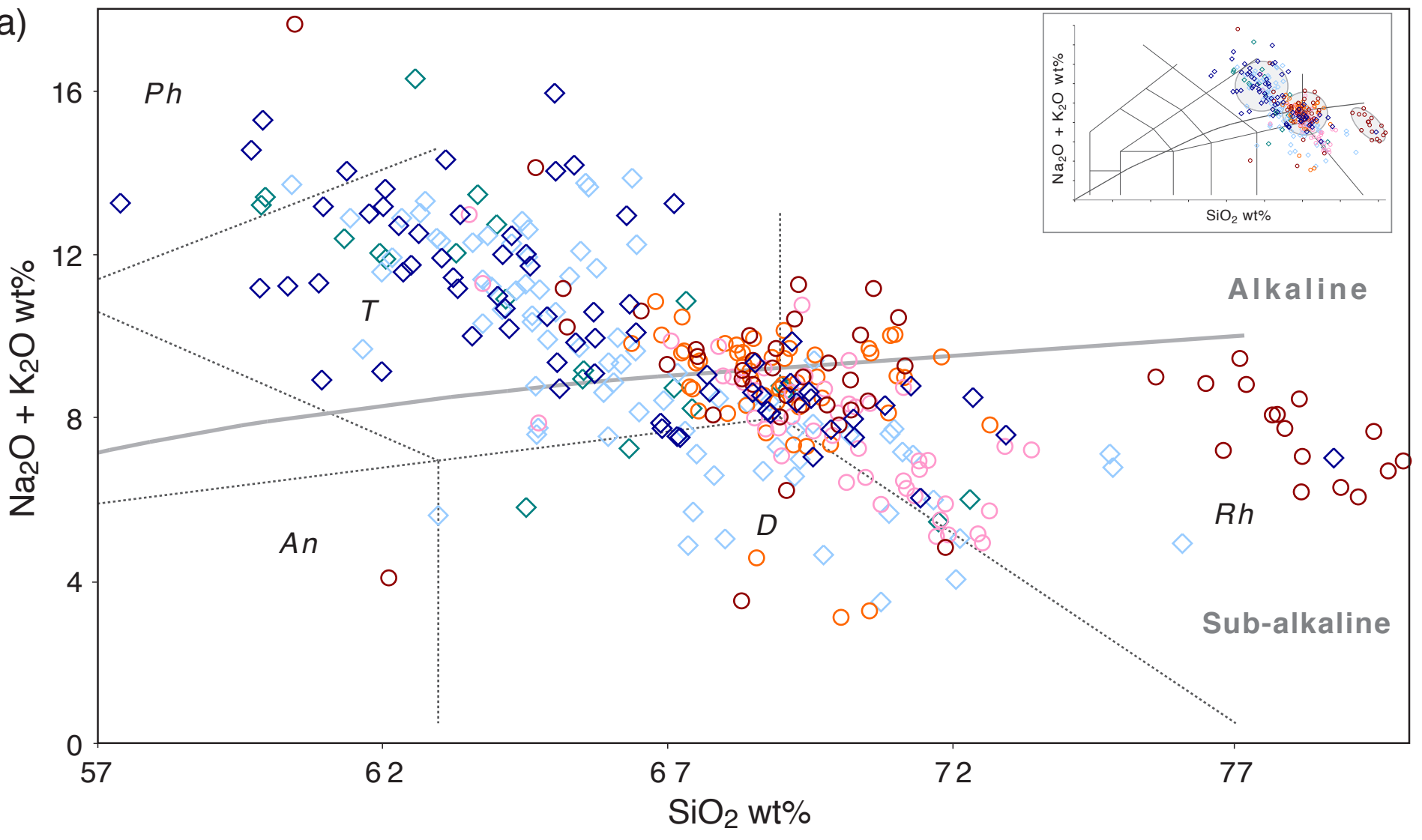

Central Plateau

Peripheral Plateau

$\circ$ DC71-a $\bigcirc$ VK-14 O VK -16

$\diamond$ TD87 -1 $\diamond$ TD86 -2 to 4

GV7

(b)

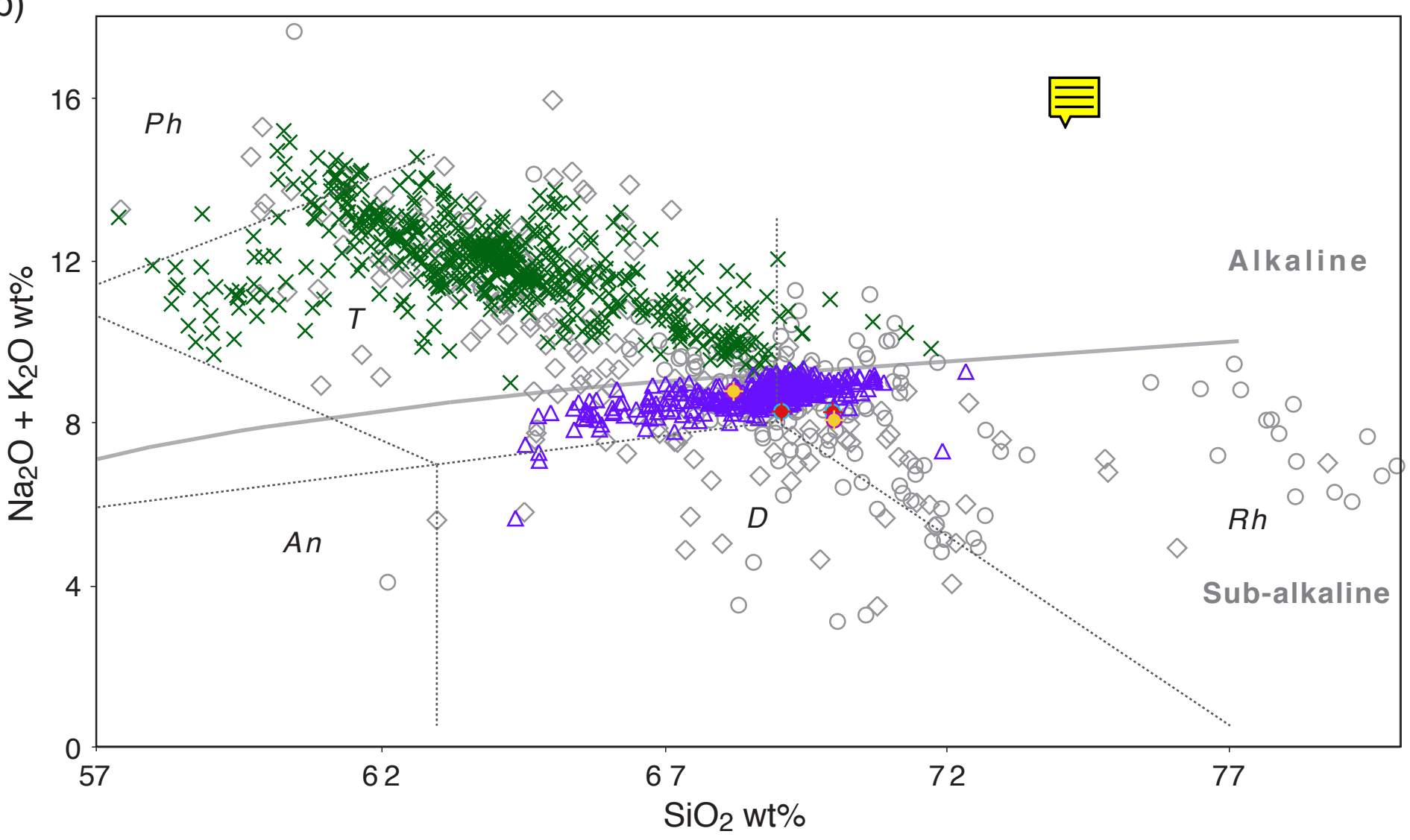




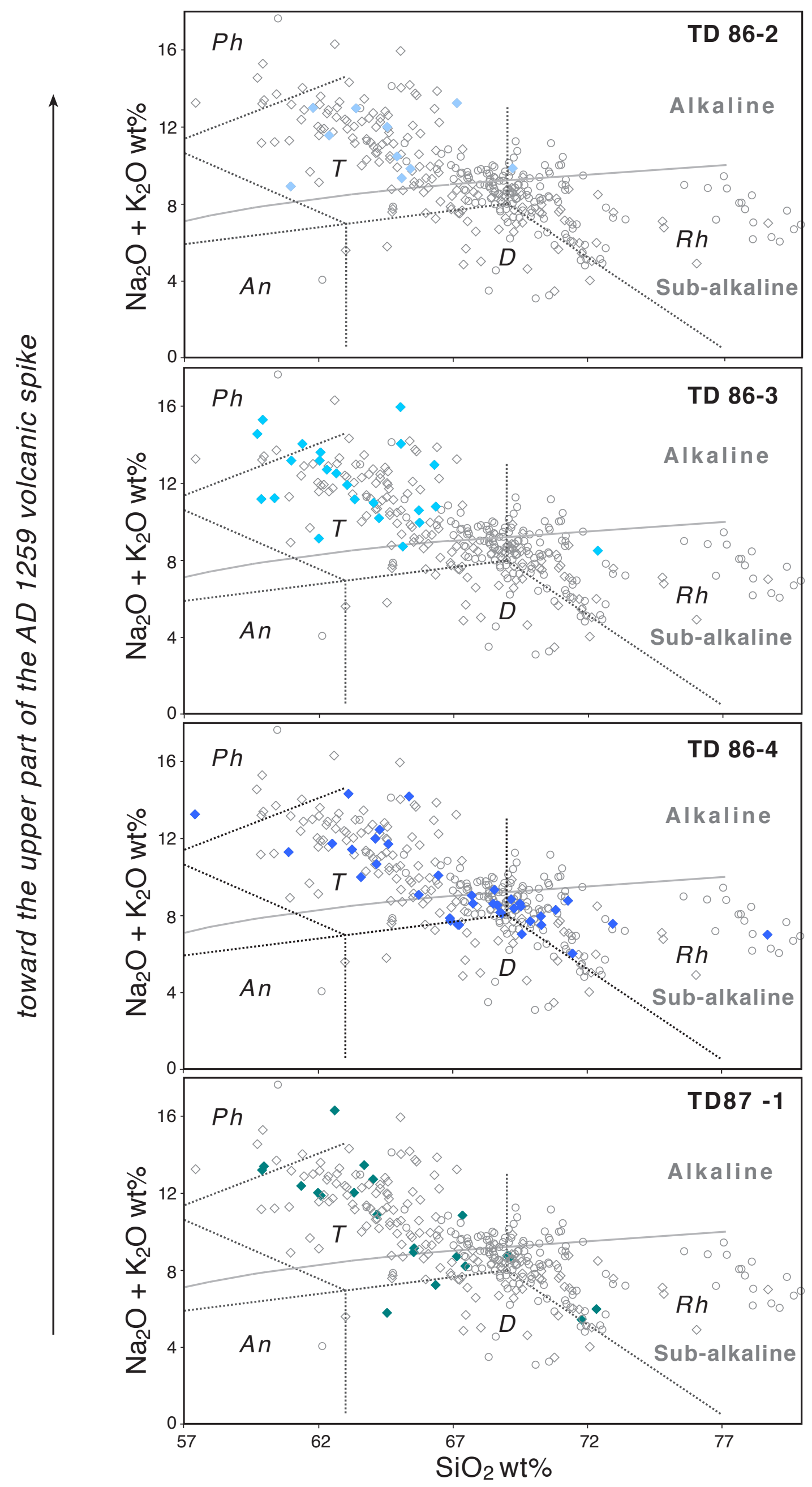


1 Supplementary Material for

2

3

MULTIPLE SOURCES FOR TEPHRA FROM AD 1259 VOLCANIC SIGNAL IN ANTARCTIC ICE CORES

4

5 Biancamaria Narcisi ${ }^{1}$, Jean Robert Petit ${ }^{2}$, Barbara Delmonte ${ }^{3}$, Valentina Batanova ${ }^{4}$, Joël 6 Savarino ${ }^{2}$

7

8

(1) ENEA, C.R. Casaccia, 00123 Roma, Italy, biancamaria.narcisi@enea.it

10

(2) Univ. Grenoble Alpes, CNRS, IRD, Grenoble INP, IGE, 38000 Grenoble, France

11 (3) Department of Earth and Environmental Sciences (DISAT), Univ. Milano-Bicocca, Piazza della Scienza, 20126 12 Milano, Italy

13 (4) Univ. Grenoble Alpes, Univ. Savoie Mont Blanc, CNRS, IRD, IFSTTAR, ISTerre, 38000 Grenoble, France 


\begin{tabular}{|c|c|c|c|c|c|c|}
\hline $\begin{array}{l}\text { Drilling Site/Ice } \\
\text { core }\end{array}$ & $\begin{array}{l}\text { Short } \\
\text { name }\end{array}$ & $\begin{array}{l}\text { Location,ele } \\
\text { vation a.s.l. }\end{array}$ & $\begin{array}{l}\text { Accumulation rate } \\
\text { (mm we year-1) }\end{array}$ & $\begin{array}{l}\text { Drilling } \\
\text { period }\end{array}$ & Reference & $\begin{array}{l}\text { Present } \\
\text { sample } \\
\text { resolution } \\
(\mathrm{cm})\end{array}$ \\
\hline $\begin{array}{l}\text { Concordia Station } \\
\text { at Dome C }\end{array}$ & DC & $\begin{array}{l}75^{\circ} 06^{\prime} \mathrm{S} \\
123^{\circ} 20^{\prime} \mathrm{E} \\
3220 \mathrm{~m}\end{array}$ & $\sim 25$ & 2013-14 & Schwander et al. (2001) & 7 \\
\hline Vostok/BH6 & VK & $\begin{array}{l}78^{\circ} 28^{\prime} \mathrm{S}, \\
106^{\circ} 48^{\prime} \mathrm{E}, \\
3488 \mathrm{~m}\end{array}$ & $\sim 20$ & 1991- 92 & Osipov et al. (2014) & 5 \\
\hline $\begin{array}{l}\text { Talos } \\
\text { Dome/TALDICE }\end{array}$ & TD & $\begin{array}{l}72^{\circ} 49^{\prime} \mathrm{S} \\
159^{\circ} 11^{\prime} \mathrm{E} \\
2315 \mathrm{~m}\end{array}$ & $\sim 80$ & $2004-05$ & Severi et al. (2012) & 5 \\
\hline GV7 & GV7 & $\begin{array}{l}70^{\circ} 41^{\prime} \mathrm{S}, \\
158^{\circ} 52^{\prime} \mathrm{E}, \\
1950 \mathrm{~m}\end{array}$ & $\sim 240$ & $2013-14$ & $\begin{array}{l}\text { Frezzotti et al. (2007) Caiazzo } \\
\text { et al. (2017) }\end{array}$ & 15 \\
\hline
\end{tabular}

14

15 Table S1. Location and characteristics of the studied ice cores

16

17

18

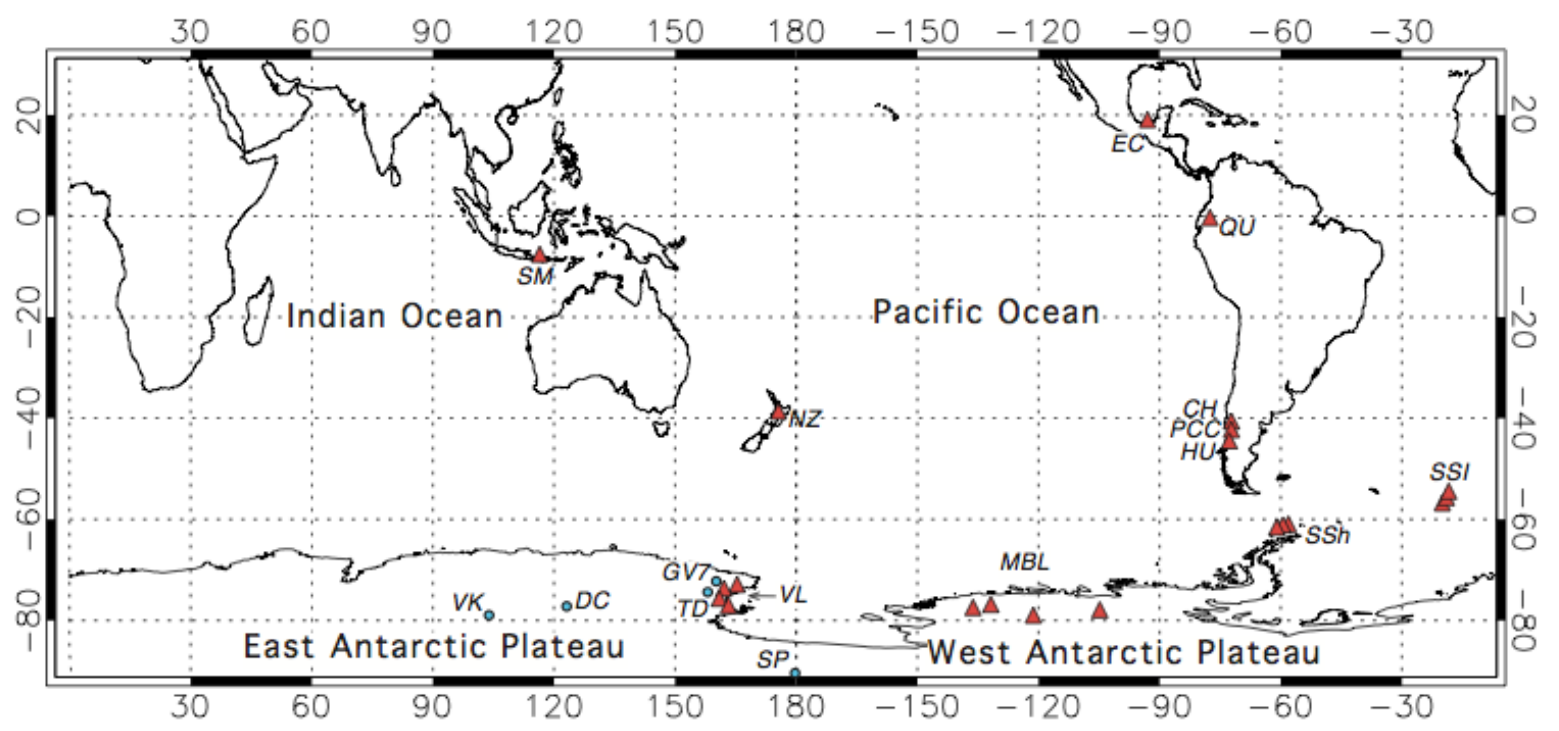

20 Figure S1. World map showing the location of Antarctic ice core sites (blue dots) and of selected volcanic sources considered in the text (red triangles). Letters for sources are as follows. CH, Chaitén; EC, El Chichón; HU, Hudson; MBL, Marie Byrd Land; NZ, New Zealand; PCC, Puyehue-Cordon Caulle; QU, Quilotoa; SM, Samalas; SSh, South 


\section{Details of microprobe analysis}

Although tephra embedding and polishing should be preferred for microprobe analysis, this was not possible here due to the small amount of material and its very fine grain size. Therefore, single-grain geochemical analysis was carried out on unpolished samples using a JEOL JXA-8230 electron microprobe set up at the Institut des Sciences de Terre (ISTerre) of Grenoble. For analysis of small $(1-3 \mu \mathrm{m})$ and thin $(<2 \mu \mathrm{m})$ unpolished tephra shards the analytical protocol with simultaneous WDS/EDS signal acquisition has been applied. We run $\mathrm{Ti}, \mathrm{Na}, \mathrm{Mg}, \mathrm{K}$, and $\mathrm{Fe}$ on WD spectrometers and $\mathrm{Si}, \mathrm{Ca}, \mathrm{Al}$, on ED spectrometers. The following analytical conditions have been used: accelerating voltage $10 \mathrm{kV}$, probe beam current $2 \mathrm{nA}$ and beam diameter $1 \mu \mathrm{m}$. The low accelerating voltage was selected to reduce $X$-ray excitation volume. Natural and synthetic minerals and glasses were used for standardisation: StHs6/80-G (Si, Al, Ca) and GOR132-G (Fe) synthetic glasses (Jochum et al, 2000 and GEOREM database), pure synthetic MgO (Mg), synthetic rutile $(\mathrm{Ti})$, albite $(\mathrm{Na})$, orthoclase $(\mathrm{K})$. During analytical sessions the reference materials StHs6/80-G, ATHO-G (Jochum et al., 2000) and KE-12 (Metrich and Rutherford, 1992) ran as unknowns after each 40-50 analytical points to evaluate analytical accuracy and precision. Even at current as low as $2 \mathrm{nA}$ the migration of sodium could be significant if the diameter of the electron beam is small $(1 \mu \mathrm{m})$. The results of analysis of reference glasses and polished tephra samples analysed at traditional (Acc. voltage $15 \mathrm{kV}$, probe current $5 \mathrm{nA}$, beam diameter $5 \mu \mathrm{m}$, e.g. Narcisi et al., 2016) and non-traditional (Acc. voltage 10kV, beam current 2nA, probe diameter 1 $\mu \mathrm{m}$, this study) are in Table S2. We estimate that Na loss for polished samples analysed by $1 \mu \mathrm{m}$ beam and non-traditional analytical conditions described above corresponds to $25 \%$ relative for samples with 4-7 wt\% of $\mathrm{Na}_{2} \mathrm{O}$ and $67-75$ wt\% of $\mathrm{SiO}_{2}$ (ATHO-G, KE-12, and samples RIN1392E and RIN1392A related to the AD 1257 Samalas medial tephra, Vidal et al., 2015) (Table S2). As it has been shown in several studies (e.g. Nielsen and Sigurdsson, 1981; Spray and Rae, 1995; Morgan and London, 1996) sodium migration from the excitation volume is a result of heating of the area of analysis by electron beam. According to Spray and Rae (1995) sodium migrates downward to space-charge layer within the sample. Figure S2 shows Monte Carlo electron trajectory simulation of the interaction volume as well as $\mathrm{Na}-\mathrm{K} \alpha$ generation and emission volumes for $10 \mathrm{kV}$ in common polished sample and unpolished $1 \times 1 \mu \mathrm{m}$ particle on filter. These figures demonstrated how electron beam penetrates the samples of the different morphology. As follows from the modelling in case of analysis of small shards the Na migration does not take place because of small sample size. Analysis of small tephra shards often displayed low analytical total (30-60\%). Low and variable totals of analysis are result of small size of analytical area (smaller than excitation volume) (Figure S2-B). The analytical precision for the selected analytical conditions is in Table S2. While the analytical precision at $10 \mathrm{kV}$ and $2 \mathrm{nA}$ for the most analysed oxides is significantly lower than for traditional conditions it is still within reasonable error (5-15\%). 
A

$\mathrm{Na} \mathrm{Ka} 10 \mathrm{kV}$

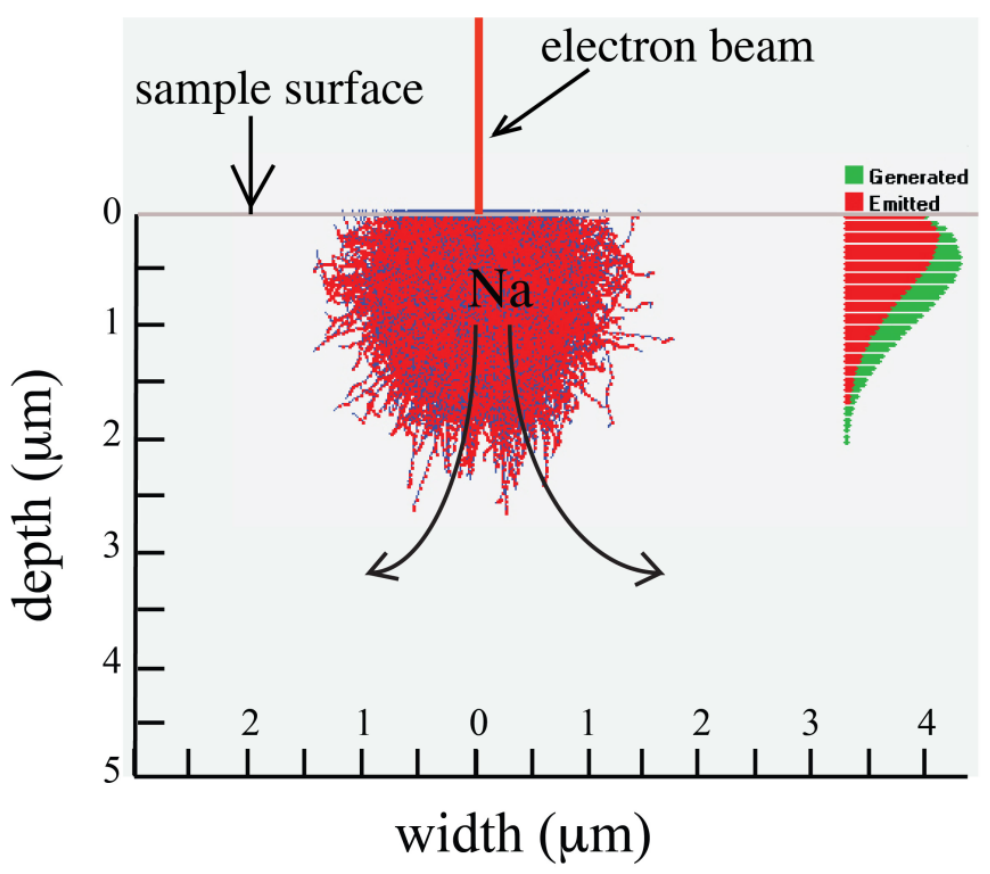

B

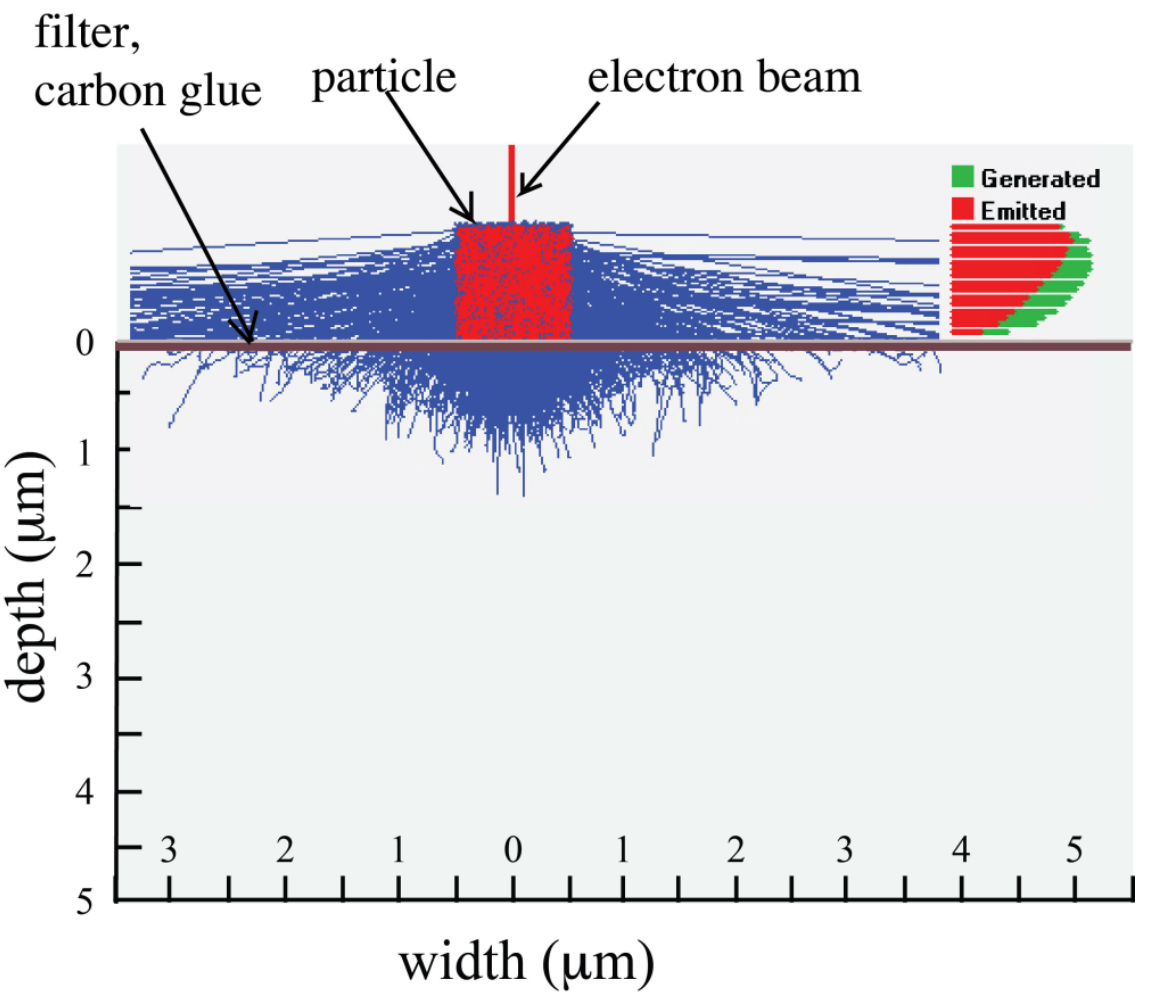

Figure S2. Monte Carlo simulation of the interaction and emission volumes of X-rays at $10 \mathrm{kV}$ for $\mathrm{Na}-\mathrm{K} \alpha$ in Na-Si rich glass considered as A) common polished sample and B) small $1 \times 1 \mu \mathrm{m}$ particle placed on the C-glue. The blue lines show the electron trajectory outside the particle. 
Table S2. Composition of reference glasses and Samalas tephra samples measured at different analytical conditions

\begin{tabular}{|c|c|c|c|c|c|c|c|c|c|c|c|c|c|}
\hline Sample & Reference & $\begin{array}{l}\text { Analytical } \\
\text { conditions }\end{array}$ & $\mathbf{N}$ & $\mathrm{SiO}_{2}$ & $\mathrm{TiO}_{2}$ & $\mathrm{Al}_{2} \mathrm{O}_{3}$ & FeOtot & MnO & MgO & $\mathrm{CaO}$ & $\mathrm{Na}_{2} \mathrm{O}$ & $\mathrm{K}_{2} \mathrm{O}$ & Total \\
\hline StHs6/80-G & this work & $10 \mathrm{kV}, 2 \mathrm{nA}, 1 \mu \mathrm{m}$ & 15 & 63,56 & 0,69 & 17,61 & 4,46 & & 1,95 & 5,38 & 4,33 & 1,29 & 99,28 \\
\hline \pm & & & & 0,45 & 0,10 & 0,33 & 0,26 & & 0,11 & 0,33 & 0,30 & 0,04 & \\
\hline StHs6/80-G & this work & $15 \mathrm{kV}, 5 \mathrm{nA}, 5 \mu \mathrm{m}$ & 15 & 63,73 & 0,69 & 17,86 & 4,29 & 0,08 & 1,94 & 5,26 & 4,62 & 1,28 & 99,75 \\
\hline \pm & & & & 0,21 & 0,01 & 0,18 & 0,08 & 0,03 & 0,04 & 0,06 & 0,12 & 0,03 & \\
\hline StHs6/80-G & Jochum et al. (2000) (a) & & & 63,70 & 0,70 & 17,80 & 4,37 & 0,08 & 1,97 & 5,28 & 4,44 & 1,29 & 99,63 \\
\hline $95 \% C L$ & & & & 0,50 & 0,02 & 0,20 & 0,07 & 0,00 & 0,04 & 0,09 & 0,14 & 0,02 & \\
\hline ATHO-G & this work & $10 \mathrm{kV}, 2 \mathrm{nA}, 1 \mu \mathrm{m}$ & 12 & 75,64 & 0,26 & 11,95 & 3,14 & & 0,09 & 1,72 & 2,79 & 2,61 & 98,20 \\
\hline \pm & & & & 0,59 & 0,04 & 0,21 & 0,27 & & 0,03 & 0,25 & 0,47 & 0,08 & \\
\hline ATHO-G & this work & $15 \mathrm{kV}, 5 \mathrm{nA}, 5 \mu \mathrm{m}$ & 12 & 75,88 & 0,24 & 12,30 & 3,14 & 0,11 & 0,09 & 1,71 & 3,98 & 2,64 & 100,08 \\
\hline \pm & & & & 0,32 & 0,02 & 0,21 & 0,06 & 0,03 & 0,01 & 0,03 & 0,10 & 0,04 & \\
\hline ATHO-G & Jochum et al. (2000) (a) & & & 75,60 & 0,26 & 12,20 & 3,27 & 0,11 & 0,10 & 1,70 & 3,75 & 2,64 & 99,62 \\
\hline $95 \% C L$ & & & & 0,70 & 0,02 & 0,20 & 0,10 & 0,01 & 0,01 & 0,03 & 0,31 & 0,09 & \\
\hline KE-12 & this work & $10 \mathrm{kV}, 2 \mathrm{nA}, 1 \mu \mathrm{m}$ & 12 & 71,56 & 0,32 & 7,92 & 8,93 & & 0,01 & 0,39 & 5,36 & 4,09 & 98,60 \\
\hline \pm & & & & 0,45 & 0,08 & 0,20 & 0,45 & & 0,02 & 0,20 & 0,23 & 0,09 & \\
\hline $\mathrm{KE}-12$ & this work & $15 \mathrm{kV}, 5 \mathrm{nA}, 5 \mu \mathrm{m}$ & 12 & 71,01 & 0,30 & 7,84 & 8,30 & 0,26 & 0,03 & 0,37 & 7,01 & 4,23 & 99,35 \\
\hline \pm & & & & 0,33 & 0,01 & 0,11 & 0,08 & 0,03 & 0,02 & 0,01 & 0,17 & 0,04 & \\
\hline $\mathrm{KE}-12$ & Metrich and Rutherford (1992) (b) & & & 70,30 & 0,33 & 7,60 & 8,36 & 0,26 & nd & 0,35 & 7,28 & 4,27 & 98,75 \\
\hline KE-12 & Vidal et al. (2015) (c) & & 5 & 69,93 & 0,33 & 7,64 & 8,47 & 0,31 & 0,03 & 0,37 & 6,91 & 4,26 & 98,25 \\
\hline \pm & & & & 0,38 & 0,05 & 0,22 & 0,20 & 0,08 & 0,01 & 0,03 & 0,34 & 0,04 & \\
\hline RIN1392E & this work & $10 \mathrm{kV}, 2 \mathrm{nA}, 1 \mu \mathrm{m}$ & 41 & 68,25 & 0,45 & 15,19 & 2,43 & & 0,58 & 1,67 & 2,90 & 4,10 & 96,29 \\
\hline \pm & & & & 0,93 & 0,06 & 0,38 & 0,25 & & 0,11 & 0,28 & 0,50 & 0,24 & \\
\hline RIN1392E & this work & $15 \mathrm{kV}, 5 \mathrm{nA}, 5 \mu \mathrm{m}$ & 26 & 68,38 & 0,45 & 15,41 & 2,40 & 0,12 & 0,58 & 1,67 & 4,52 & 4,45 & 97,97 \\
\hline \pm & & & & 0,48 & 0,01 & 0,27 & 0,09 & 0,02 & 0,09 & 0,09 & 0,29 & 0,11 & \\
\hline RIN1392E & Vidal et al. (2015) (c) & & 10 & 70,09 & 0,47 & 15,65 & 2,51 & 0,14 & 0,60 & 1,80 & 3,52 & 4,39 & 99,17 \\
\hline \pm & & & & 0,69 & 0,07 & 0,28 & 0,10 & 0,07 & 0,05 & 0,21 & 0,47 & 0,22 & \\
\hline RIN1392A & this work & $10 \mathrm{kV}, 2 \mathrm{nA}, 1 \mu \mathrm{m}$ & 48 & 67,95 & 0,45 & 16,05 & 2,81 & & 0,74 & 2,22 & 3,59 & 3,99 & 98,68 \\
\hline \pm & & & & 0,65 & 0,07 & 0,26 & 0,22 & & 0,07 & 0,25 & 0,35 & 0,10 & \\
\hline RIN1392A & this work & $15 \mathrm{kV}, 5 \mathrm{nA}, 5 \mu \mathrm{m}$ & 48 & 67,67 & 0,45 & 16,16 & 2,66 & 0,12 & 0,72 & 2,18 & 4,73 & 4,11 & 98,81 \\
\hline \pm & & & & 0,49 & 0,02 & 0,21 & 0,07 & 0,02 & 0,02 & 0,05 & 0,19 & 0,06 & \\
\hline RIN1392A & Vidal et al. (2015) (c) & & 16 & 68,24 & 0,46 & 16,11 & 2,70 & 0,11 & 0,73 & 2,22 & 4,69 & 4,16 & 99,42 \\
\hline \pm & & & & 0,77 & 0,07 & 0,31 & 0,12 & 0,05 & 0,04 & 0,13 & 0,19 & 0,11 & \\
\hline
\end{tabular}

Notes: Oxides reported in wt\%. $\mathrm{N}$ - number of analyses. Reproducibility ( \pm ) is shown as 1 standard deviation of average.

(a) reference values; (b) whole rock data; (c) EPMA data.

Table S2. Composition of reference glasses and Samalas tephra samples measured at different analytical conditions. 
Our attempte. urce identification was based upon comparison with bibliographic information for volcanoes that have been active during post-glacial times. We considered as constraining features the chronostratigraphy of the deposits, the character of volcanic activity and the chemical signature of the material. However, a matching source depends on the data available in the literature. Inaccessible volcanoes may bє vided with stratigraphic records that are still incomplete or poorly age constrained. The possibility that our tephra may represent a hitherto unknown eruption in the proximal sequence cannot be entirely excluded. As for chemical features of deposits from proximal contexts, in order to avoid misleading correlations we took into account only sources for which single-shard microprobe data are available. We consider in fact bulk-rock analyses of near-vent samples, often affected by the presence of minerals on xenoliths, unsuitable for comparison with the present shard-specific dataset. However, we are aware that proximal and distal tephra components of the same eruption may have slightly different compositions and this may represent a further problem of our approach. On the other hand, here we considered a large set of possible volcanic sources within and surrounding the Antarctic continent, more extended than that employed in previous studies. This strategy, requiring scrutiny of a high number of relevant published papers, allowed us to confidently rule out clearly dissimilar sources and to ascribe the investigated ice-core tephra to the parent eruption.

Figure S1 illustrates location of a few volcanoes considered in this discussion. Graphical comparison of the composition of individual ice-core shards with glass analyses from proximal source deposits (Figure S3) supports the following considerations.

Regardless of age of proximal activity, we could readily exclude volcanism of South Sandwich Islands (SSI) in the Southern Atlantic Ocean, producing several tephras preserved in Central EAP (e.g., Narcisi et al., 2010, and references therein), because of its low-K tholeiitic nature (e.g., Nielsen et al., 2007), as well as volcanoes in the Soith Shetland Islands (Antarctic Peninsula

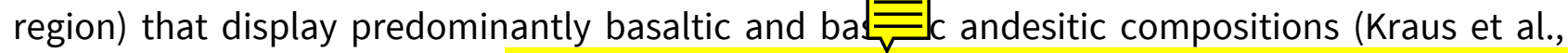
2013; Antoniades et al., 2018). Both provinces are clearly dissimilar in composition with the icecore glass.

Careful attention was paid to post-glacial volcanoes of the Andean belt representing very efficient producers of sub-alkaline (calc-alkaline) tephra. These could be eligible candidates considering that the westerly atmospheric circulation penetrating the EAP favours the rapid transport and deposition of dust and tephra from South America to Antarctica (e.g., Pitts and Thomason, 1993; Delmonte et al., 2008; Narcisi et al., 2012; Koffman et al., 2017). On the basis of numerous studies over the last decades, the eruptive chronologies of many of these volcanic centres are well constrained, thus helping us to rule out a number of them.

111 In particular, in the Southern and Austral Volcanic Zones of the Andes (latitudes between 33 to $11255^{\circ} \mathrm{S}$ ) about 20 volcanoes produced explosive eruptions with significant regional or even 113 hemispheric impact (Fontijn et al., 2014). However, the largest Holocene explosive eruptions of 114 volcanoes in the southernmost Andes producing regionally widespread tephra layers are dated back at least to $3 \mathrm{ka}$ (Stern, 2008) and so are too old to be related with the studied tephra. Other volcanoes of the Southern Volcanic Zone that either are too old or do not show geological 
117 evidence of energetic explosive activity in mid- $13^{\text {th }}$ century to be considered as likely sources are

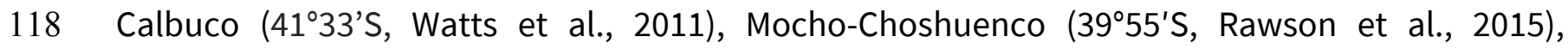
119 Quetrupillán (39³0' S, Fontjin et al., 2016), Sollipulli (3858'S; Naranjo et al., 1993), Lonquimay

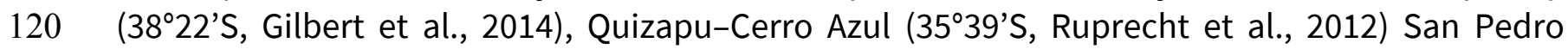
121 (36 S, Singer et al., 1997). Similarly, we can exclude volcanoes of the Central Volcanic Zone of 122 the Andes (latitudes between $14^{\circ}$ and $29^{\circ} \mathrm{S}$ ) characterised by high-K calc-alkaline compositions. 123 Here, the two last major explosive events were the 2-ka BP plinian eruption of El Misti volcano 124 (Thouret et al., 2001) and the AD 1600 eruption of Huaynaputina volcano (e.g., Lavallée et al., 2006), both inconsistent with age of the ice tephra sample. The remaining explosive activity was small to moderate, so most likely not capable of dispersing ash onto the Antarctic ice sheet. Farther north, also at the Andean volcanoes of Chimborazo ( ${ }^{\circ} 28^{\prime} S$, Barba et al., 2008) and Cotopaxi $\left(0^{\circ} 38^{\prime} \mathrm{S}\right.$, Hall and Mothes, 2008) the recorded activity is not appropriate as either age or character to suggest a linkage with our tephra. In the Northern Hemisphere, according to marine tephrostratigraphy offshore the southern Central American Volcanic Arc $\left(7-9^{\circ} \mathrm{N}\right)$ documenting explosive activity of Costa Rica and Nicaragua volcanoes, the most recent marker is 3.5 ka old (Schindlbeck et al., 2016), thus much older than our ice-core tephra. Terrestrial volcanostratigraphies of Irazù $\left(9^{\circ} 58^{\prime} \mathrm{N}\right.$, Benjamin et al., 2007), Apoyeque $\left(12^{\circ} 14^{\prime} \mathrm{N}\right.$, Kutterolf et al., 2011) and Ilopango $\left(13^{\circ} 67^{\circ} \mathrm{N}\right.$, Mehringer et al., 2005) do not show any suitable tephra deposit of appropriate age. The voluminous eruption of El Metate $\left(19^{\circ} 32^{\prime} \mathrm{N}\right.$, Mexico) dated at $\sim A D 1250$ was purelv effusive (Chevrel et al., 2015), making it an unlikely candidate.

We carried out a comparison between our glacc-shard microprobe data and the composition of selected calc-alkaline tephra sources active le last millennium (Figure S3). In particular, we considered recent explosive products of the/American volcanoes of Chaitén $\left(42^{\circ} 49^{\prime} \mathrm{S}\right.$, Moreno et al., 2015), Puyehue-Cordon Caulle ( $40^{\circ} 59^{\prime} \mathrm{S}$, Mil Hojas tephra, modelled age $0.84 \pm 0.18 \mathrm{cal}$ ka BP, Fontijn et al., 2016), Hudson ( $45^{\circ} 54^{\prime} \mathrm{S}$, Kratzmann et al., 2009), Quilotoa ( AD 1280, $0^{\circ} 51$ 's, Stewart and Castro, 2016), El Chichón ( $6^{\text {th }}$-century deposits, $17^{\circ} 22^{\prime} \mathrm{N}$, Nooren et al., 2017) along with tephra erupted during the Kaharoa e 2004) and from Marie Byrd Land volcanoes round in the marine realm (Shane and Froggatt, 1992). It can be seen that none of these satisfactorily fit the dacitic chemistry of the ice-core tephra component and consequently cannot be likely counterparts. Note that El Chichón volcano was previously suggested as a probable source for the polar tephra in the South Pole (SP) and Greenland ice cores (Palais et al., 1992). Although the El Chichón historic volcanic record does not preclude this possibility (Espíndola et al., 2000), the present comparison highlights appreciable compositional differences between the studied dacitic tephra and the proximal volcanic deposits, thus excluding the former attribution.

We finally found/pusicive chemical match between dacitic glass shards trapp vithin ice and products of $A D 1257$ Samalas volcanic n...ption, the cataclysmic event/uccurred in the Indonesian Archipelago ( $\left.8^{\circ} 33^{\prime} \mathrm{S}\right)$ and far ${ }_{2}^{x}$ among the greatest volcanic events of the Holocene (e.g., Lavigne et al., 2013; Vidal et a' 2015, 2016; Alloway et al., 2017) (Figure 4b, main text). Note that our chemical results are also r rent with microprobe data of Samalas samples analysed within this work (Table S2). 


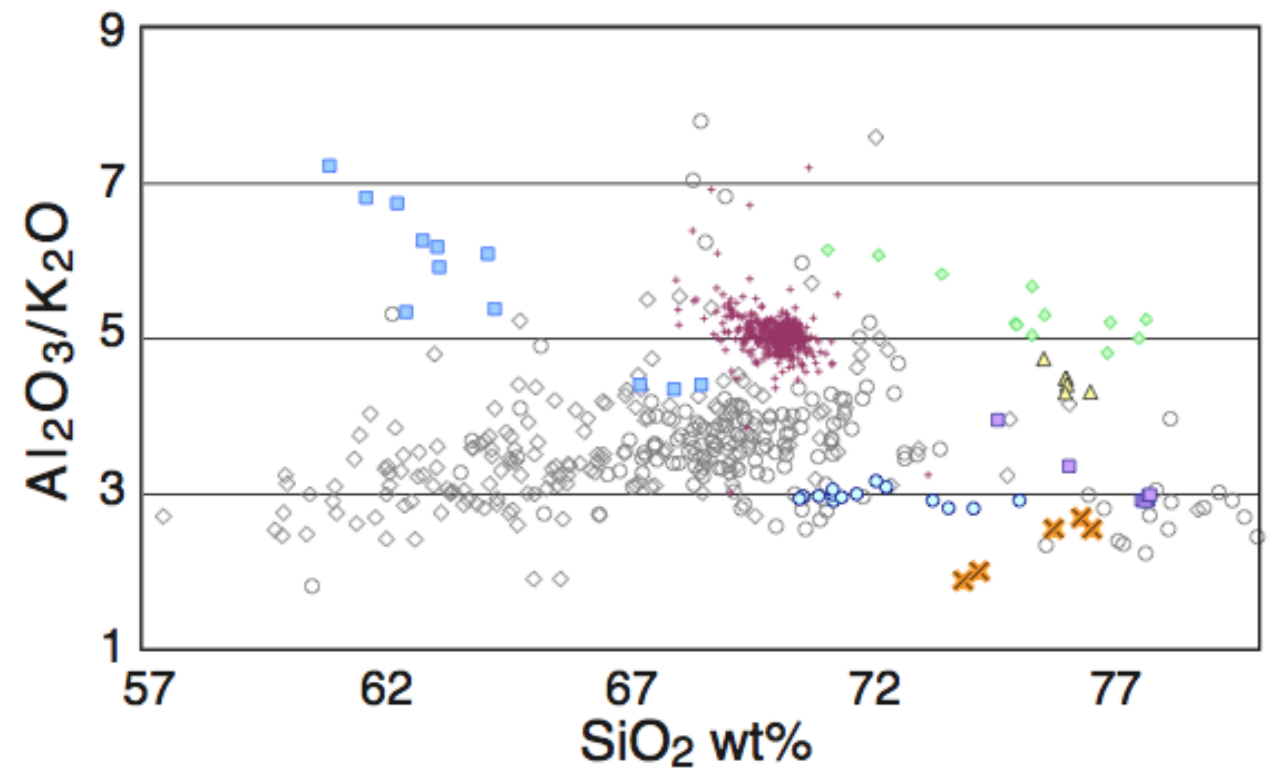

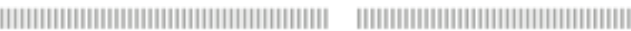

Trachyte

Dacite

Rhyolite

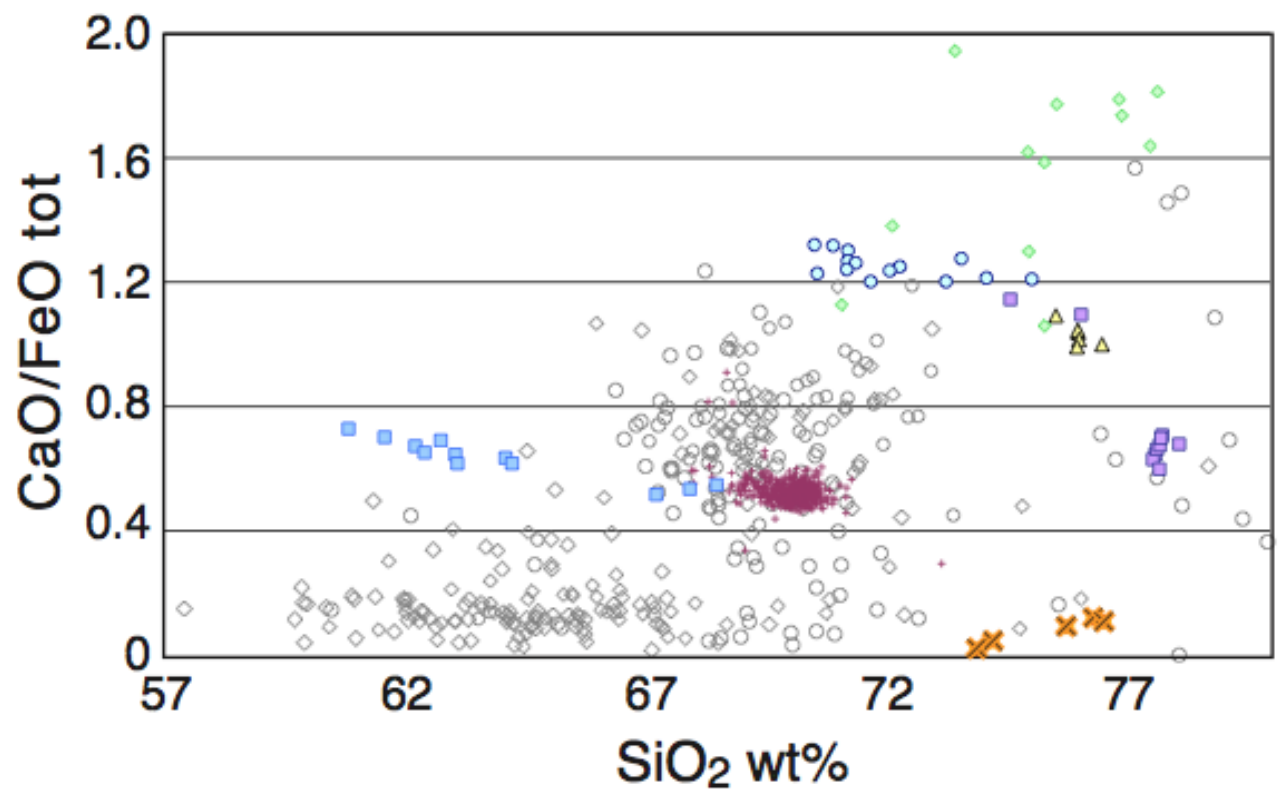

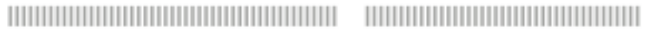

Trachyte

Dacite

Rhyolite
Central Plateau
Peripheral Plateau
$\Delta$ Chaitén
Puyehue-C. Caulle
El Chichon - Hudso
- Quilotoa
- NZ-Kaharoa
$\times$ West Antartic marine tephra

Figure S3. Major element biplots for the analysed ice-core shards (in grey-scale) compared with glass geochemical analyses for selected potential sources and counterparts (data from Moreno et al., 2015; Fontijn et al., 2016; Nairn et al., 2004; Kratzmann et al., 2009; Nooren et al., 2017; Stewart and Castro, 2016; Shane and Froggatt, 1992). Location of considered source volcanoes is shown in Supplementary Figure S1. 


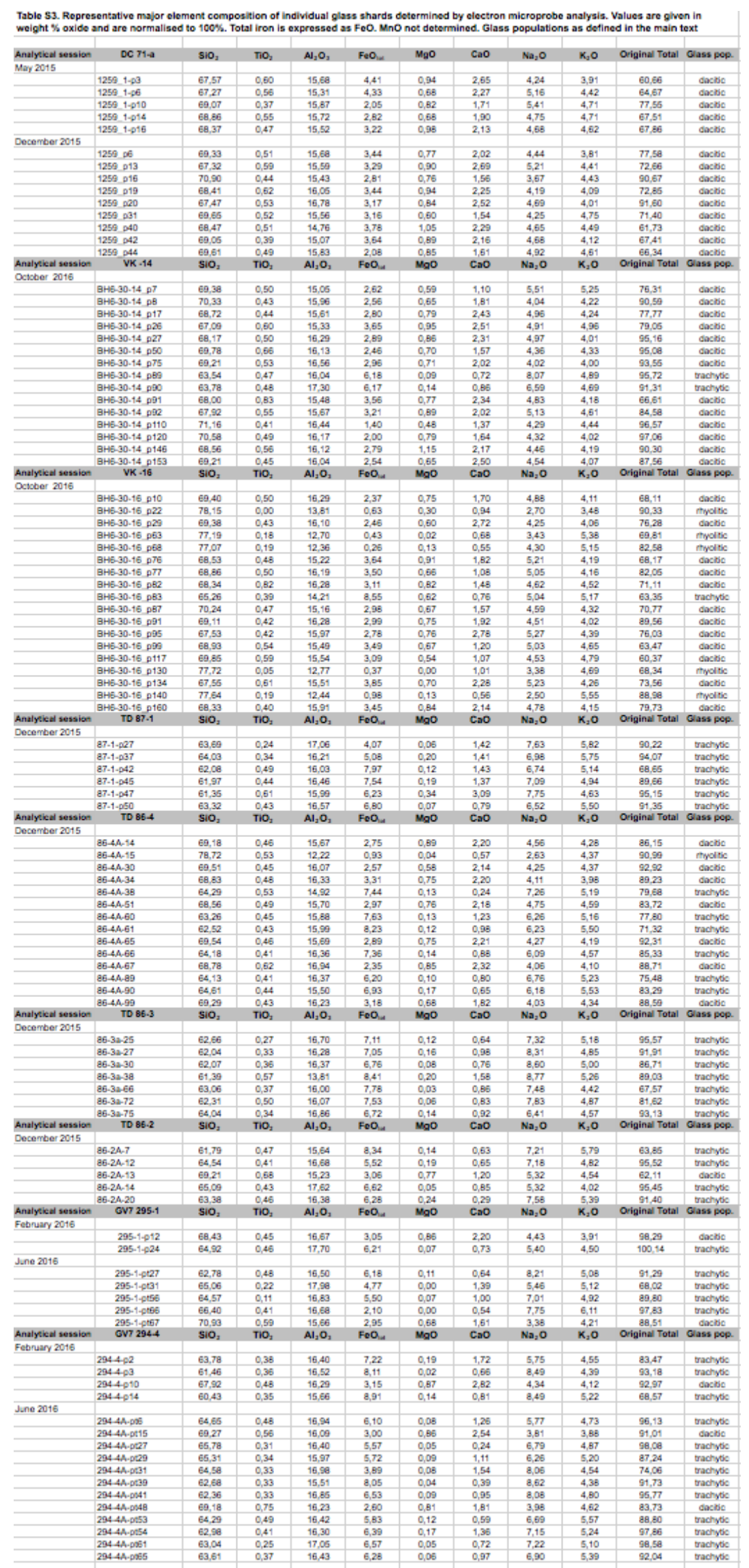

165 Table S3. Representative major element composition of individual glass shards determined by electron microprobe 166 analysis. Values are given in weight \% oxide and are normalised to $100 \%$. Total iron is expressed as FeO. MnO not 167 determined. Glass populations as defined in the main text. 
Alloway, B.V., Supriyati Andreastuti, Ruly Setiawan, John Miksic, Quan Hua (2017). Archaeological implications of a widespread 13th Century tephra marker across the central Indonesian Archipelago. Quaternary Science Reviews 155, 86-99. https://doi.org/10.1016/j.quascirev.2016.11.020

Antoniades, D., Giralt, S., Geyer, A., Álvarez-Valero, A.M., Pla-Rabes, S., Granados, I., Liu, E.J., Toro, M., Smellie, J.L., Oliva, M. (2018). The timing and widespread effects of the largest Holocene volcanic eruption in Antarctica. Scientific Reports 8, 1-11, DOI:10.1038/s41598-018-35460-x

Barba, D., Robin, C., Samaniego, P., Eissen, J.-P. (2008). Holocene recurrent explosive activity at Chimborazo volcano (Ecuador). Journal of Volcanology and Geothermal Research 176 (1), 27-35, https://doi.org/10.1016/j.jvolgeores.2008.05.004

Benjamin, E.R., Plank, T., Wade, J.A., Kelley, K.A., Hauri, E.H., Alvarado, G.E. (2007). High water contents in basaltic magmas from Irazú Volcano, Costa Rica. Journal of Volcanology and Geothermal Research 168, 68-92, https://doi.org/10.1016/j.jvolgeores.2007.08.008

Caiazzo, L., Baccolo, G., Barbante, C., Becagli, S., Bertò, M., Ciardini, V., Crotti, I., Delmonte, B., Dreossi, G., Frezzotti, M. et al. (2017). Prominent features in isotopic, chemical and dust stratigraphies from coastal East Antarctic ice sheet (Eastern Wilkes Land). Chemosphere 176, 273-287, https://doi.org/10.1016/j.chemosphere.2017.02.115

Chevrel, M., Siebe, C. Guilbaud, M.N. Salinas, S. (2015). The AD 1250 El Metate shield volcano (Michoacán): Mexico's most voluminous Holocene eruption and its significance for archaeology and hazards. The Holocene 26, 471-488, DOI: $10.1177 / 0959683615609757$

Delmonte, B., Andersson, P.S., Hansson, M., Schöberg, H., Petit, J.R., Basile-Doelsch, I., Maggi, V. (2008). Aeolian dust in East Antartica (EPICA-Dome C and Vostok): Provenance during glacial ages over the last 800 kyr. Geophysical Research Letters 35 L07703, doi:10.1029/2008GL033382

Espíndola, J.M., Macías, J.L., Tilling, R.I., Sheridan M.F. (2000). Volcanic history of El Chichón Volcano (Chiapas, Mexico) during the Holocene, and its impact on human activity. Bulletin of Volcanology 62, 90-104.

Fontijn, K., Lachowycz, S.M., Rawson, H., Pyle, D.M., Mather, T.A., Naranjo, J.A., Moreno- Roa, H. (2014). Late Quaternary tephrostratigraphy of southern Chile and Argentina. Quaternary Science Reviews 89, 70-84.

Fontijn, K., Rawson, H., Van Daele, M., Moernaut, J., Abarzúa, A.M., Heirman, K., Bertrand, S., Pyle, D.M. et al. (2016). Synchronisation of sedimentary records using tephra: A postglacial tephrochronological model for the Chilean Lake District. Quaternary Science Reviews 137, 234-254, https://doi.org/10.1016/j.quascirev.2016.02.015

Frezzotti, M., Urbini, S., Proposito, M., Scarchilli, C., Gandolfi, S. (2007). Spatial and temporal variability of surface mass balance near Talos Dome, East Antarctica. Journal of Geophysical Research 112, F02032.

Gilbert, D., Freundt, A., Kutterolf, S. et al. (2014) Post-glacial time series of explosive eruptions and associated changes in the magma plumbing system of Lonquimay volcano, south central Chile. International Journal of Earth Sciences 103, 2043-2062, https://doi.org/10.1007/s00531-012-0796-x

Jochum, K.P., Dingwell, D.B., Rocholl, A., Stoll, B., Hofmann, A.W., Becker, S., Besmehn, A., Bessette, D., Dietze, H., Dulski, P., Erzinger, J., Hellebrand, E., Hoppe, P., Horn, I., Janssens, K., Jenner, G., Klein, M., McDonough, W. Maetz, M., Mezger, K., Müker, C., Nikogosian, I., Pickhardt, C., Raczek, I., Rhede, D., Seufert, H., Simakin, S., Sobolev, A., Spettel, B., Straub, S., Vincze, L., Wallianos, A., Weckwerth, G., Weyer, S., Wolf, D., Zimmer, M. (2000). The Preparation and Preliminary Characterisation of Eight Geological MPI-DING Reference Glasses for In-Situ Microanalysis. Geostandards Newsletter 24: 87-133, doi:10.1111/j.1751-908X.2000.tb00590.x

Hall, M., Mothes, P. (2008). The rhyolitic-andesitic eruptive history of Cotopaxi volcano, Ecuador. Bulletin of Volcanology 70, 675-702. 
Koffman, B.G., Dowd, E.G., Osterberg, E.C., Ferris, D.G., Hartman, L.H., Wheatley, S.D., et al. (2017). Rapid transport of ash and sulfate from the 2011 Puyehue-Cordón Caulle (Chile) eruption to West Antarctica. Journal of Geophysical Research: Atmospheres 122, 8908-8920, https://doi.org/10.1002/2017JD026893

Kratzmann, D.J., Carey, S., Scasso, R., Naranjo, J.A. (2009). Compositional variations and magma mixing in the 1991 eruptions of Hudson volcano, Chile. Bulletin of Volcanology 71, 419-439, doi:10.1007/s00445-008-0234

Kraus, S., Kurbatov, A., Yates, M. (2013). Geochemical signatures of tephras from Quaternary Antarctic Peninsula volcanoes: Andean Geology 40 (1), 1-40, doi:http://dx.doi.org/10.5027/andgeoV40n1-a01

Kutterolf, S., Freundt, A. \& Burkert, C. (2011). Eruptive history and magmatic evolution of the 1.9 kyr Plinian dacitic Chiltepe Tephra from Apoyeque volcano in west-central Nicaragua. Bulletin of Volcanology 73, 811-831, doi:10.1007/s00445-011-0457-0

Lavallée, Y., de Silva, S.L., Salas, G., Byrnes, J.M. (2006). Explosive volcanism (VEI 6) without caldera formation: insight from Huaynaputina volcano, southern Peru. Bulletin of Volcanology 68, 333-348, DOI 10.1007/s00445-0050010-0

Lavigne, F., Degeai, J.-P., Komorowski, J.-C., Guillet, S., Robert, V., Lahitte, P., Oppenheimer, C., Stoffel, M., Vidal, C.M., Surono, Pratomo, I., Wassmer, P., Hajdas, I., Sri Hadmoko, D., de Belizal, D., (2013). Source of the great A.D. 1257 mystery eruption unveiled, Salamas volcano, Rinjani Volcanic Complex, Indonesia. Proceedings of the National Academy of Sciences Sep 2013, 201307520; DOI: 10.1073/pnas.1307520110

Mehringer, P.J. Jr., Sarna-Wojcicki, A.M., Wollwage, L.K., Sheets, P. (2005). Age and extent of the Ilopango TBJ Tephra inferred from a Holocene chronostratigraphic reference section, Lago De Yojoa, Honduras. Quaternary Research 63(2), 199-205, https://doi.org/10.1016/j.yqres.2004.09.011

Metrich, N., Rutherford, M.J. (1992). Experimental study of chlorine behavior in hydrous silicic melts. Geochimica et Cosmochimica Acta, 56 (2), 607-616, https://doi.org/10.1016/0016-7037(92)90085-W

Moreno, P.I., Alloway, B.V., Villarosa, G., Outes, V., Henríquez, W.I., De Pol-Holz, R., Pearce, N.J.G. (2015). A pastmillennium maximum in postglacial activity from Volcán Chaitén, southern Chile. Geology 43, 47-50, doi:10.1130/G36248.1

Morgan, G.B., London, D. (1996). Optimizing the electron microprobe analysis of hydrous alkali aluminosilicate glasses. American Mineralogist 81 (9-10), 1176-1185, DOI: https://doi.org/10.2138/am-1996-9-1016

Nairn, I.A, Shane, P.R, Cole, J.W, Leonard, G.J., Self, S., Pearson, N. (2004). Rhyolite magma processes of the $\sim A D$ 1315 Kaharoa eruption episode, Tarawera volcano, New Zealand. Journal of Volcanology and Geothermal Research 131 (3-4), 265-294, https://doi.org/10.1016/S0377-0273(03)00381-0

Naranjo, J., Moreno, H., Emparan, C., Murphy, M. (1993). Volcanismo explosivo reciente en la caldera del volcan Sollipulli, Andes del Sur $\left(39^{\circ} \mathrm{S}\right)$. Revista Geológica de Chile 20 (2), 167-191, doi:http://dx.doi.org/10.5027/andgeoV20n2-a03

Narcisi, B., Petit, J.R., Delmonte, B. (2010). Extended East Antarctic ice core tephrostratigraphy. Quaternary Science Reviews 29, 21-27.

Narcisi, B., Petit, J.R., Delmonte, B., Scarchilli, C., Stenni, B. (2012). A 16,000-yr tephra framework for the Antarctic

Narcisi, B., Petit, J.R., Langone, A., Stenni, B. (2016). A new Eemian record of Antarctic tephra layers retrieved from the Talos Dome ice core (Northern Victoria Land). Global and Planetary Change 137, 69-78, http://dx.doi.org/10.1016/j.gloplacha.2015. 12.016 
Nielsen, C.H., Sigurdsson, H. (1981). Quantitative methods for electron micro-probe analysis of sodium in natural and synthetic glasses. American Mineralogist 66, 547-552.

Nooren, K., Hoek, W.Z., van der Plicht, H., Sigl, M., van Bergen, M.J., Galop, D., Torrescano-Valle, N. et al. (2017). Explosive eruption of El Chichón volcano (Mexico) disrupted $6^{\text {th }}$ century Maya civilization and contributed to global cooling. Geology 45, 175-178, doi:10.1130/G38739.1

Osipov, E.Y., Khodzher, T.V., Golobokova, L.P., Onischuk, N.A., Lipenkov, V.Y., Ekaykin, A.A., Shibaev, Y.A., Osipova, O.P. (2014). High-resolution 900 year volcanic and climatic record from the Vostok area, East Antarctica. The Cryosphere 8, 843-851.

Palais, J.M., Germani, M.S., Zielinski, G.A. (1992). Interhemispheric transport of volcanic ash from a 1259 A.D. volcanic eruption to the Greenland and Antarctic ice sheets. Geophysical Research Letters 19(8), 801-804.

Pitts, M.C., Thomason L.W. (1993). The impact of the eruptions of Mount Pinatubo and Cerro Hudson on Antarctic aerosol levels during the 1991 austral spring. Geophysical Research Letters 20, 2451-2454, https://doi.org/10.1029/93GL02160

Rawson, H., Naranjo, J.A., Smith, V.C. Fontijn, K., Pyle, D.M., Mather, T.A., Moreno, H. (2015). The frequency and magnitude of post-glacial explosive eruptions at Volcán Mocho-Choshuenco, southern Chile. Journal of Volcanology and Geothermal Research 299, 103-129.

Ruprecht P., Bergantz, G.W., Cooper, K.M., Hildreth, W. (2012). The Crustal Magma Storage System of Volcán Quizapu, Chile, and the Effects of Magma Mixing on Magma Diversity. Journal of Petrology 53 (4), 801-840, https://doi.org/10.1093/petrology/egs002

Shane, P.A.R., Froggatt, P.C. (1992). Composition of widespread volcanic glass in deep-sea sediments of the Southern Pacific Ocean: an Antarctic source inferred. Bulletin of Volcanology 54, 595-601.

Schindlbeck, J.C., Kutterolf, S., Freundt, A., Alvarado, G.E., Wang, K.-L., Straub, S.M., Hemming, S.R., Frische, M., Woodhead J.D. (2016). Late Cenozoic tephrostratigraphy offshore the southern Central American Volcanic Arc: 1. Tephra ages and provenance, Geochemistry, Geophysics, Geosystems 17, 4641-4668, doi:10.1002/2016GC006503

Schwander, J., Jouzel, J., Hammer, C.U., Petit, J.R., Udisti, R., Wolff, E. (2001). A tentative chronology for the EPICA Dome Concordia ice core. Geophysical Research Letters 28 (22), 4243-4246.

Severi, M., Udisti, R., Becagli, S., Stenni, B., Traversi, R. (2012). Volcanic synchronisation of the EPICA-DC and TALDICE ice cores for the last 42 kyr BP. Climate of the Past 8, 509-517.

Singer, B.S., Thompson, R.A. Dungan, M.A., Feeley, T.C., Nelson S.T., Pickens, J.C., Brown, L.L., Wulff, A.W., Davidson, J.P., Metzger, J. (1997). Volcanism and erosion during the past 930 k.y. at the Tatara-San Pedro complex, Chilean Andes. Geological Society of America Bulletin 109 (2), 127-142.

Spray, J.G., Rae, D.A. (1995). Quantitative electron-microprobe analysis of alkali silicate-glasses: A review and user guide. Canadian Mineralogist 33, 323-332.

Stern, C.R. (2008). Holocene tephrochronology record of large explosive eruptions in the southernmost Patagonian Andes. Bulletin of Volcanology 70, 435-454.

Stewart A.-M., Castro J.M. (2016). P-T-X evolution of the 1280 AD Quilotoa dacite. Journal of Volcanology and Geothermal Research 313, 29-43, https://doi.org/10.1016/j.jvolgeores.2015.11.024

301 Thouret, J.-C., Finizola, A., Fornari, M., Legeley-Padovani, A., Suni, J., Frechen, M. (2001). Geology of El Misti volcano 
303 Vidal, C.M., Komorowski, J.-C., Metrich, N., Pratomo, I., Kartadinata, N., Prambada, O., Michel, A., Carazzo, G., 304 Lavigne, F., Rodysill, J., Fontijn, K., Surono (2015). Dynamics of the major plinian eruption of Samalas in 1257 A.D. 305 (Lombok, Indonesia). Bulletin of Volcanology 77, 73. DOI 10.1007/s00445-015-0960-9

306 Vidal, C.M., Metrich, N., Komorowski, J.-C., Pratomo, I., Michel, A., Kartadinata N., Vincent R., Lavigne, F. (2016). The 3071257 Samalas eruption (Lombok, Indonesia): the single greatest stratospheric gas release of the Common Era. 308 Scientific Reports 6, Article number: 34868, DOI: 10.1038/srep34868

309 Watt, S.F.L., Pyle, D.M., Naranjo, J., Rosqvist, G., Mella, M., Mather, T.A., Moreno, H. (2011). Holocene 310 tephrochronology of the Hualaihue region (Andean southern volcanic zone, $\sim 42^{\circ} \mathrm{S}$ ), southern Chile. Quaternary 311 International 246, 324-343, http://dx.doi. org/10.1016/j.quaint.2011.05.029 